\title{
Comparative transcriptomic analysis of peach fruits in common and high temperature conditions
}

\author{
Xiao Wang ${ }^{1}$, Binzhong Wang ${ }^{1}$, Kailu Chen ${ }^{1}$, Zhonghuan Tian ${ }^{1}$, Chaoan Long ${ }^{1}$, and \\ Binguang $\mathrm{Ma}^{1}$ \\ ${ }^{1}$ Huazhong Agricultural University
}

May 5, 2020

\begin{abstract}
Temperature is a major environmental factor that affects fruit storage, but the underlying molecular mechanism is poorly understood. Here, the differences in transcriptome, ethylene production, pulp softening of postharvest peach fruits were compared between common and high temperature storage conditions. High temperature storage resulted in a lower level of ethylene production and a slower fruit softening due to the decreased expression levels of ethylene biosynthetic genes and softening related enzymes. The MEKK1-MKK2-MPK4/6 genes had high expression levels in response to high temperature condition. The decreased expression of pectinesterase, polygalacturonase, pectate lyase, pectin methylesterase and the increased expression of expansin were observed in high temperature treatment. A series of genes related to membrane stability also showed lower transcription levels, such as peroxidase, lipoxygenase 3 and superoxide dismutase $1 / 2$. These genes were co-expressed with different auxin response factors, ethylene response factors and they composed function modules collectively correlated to physiological changes. Finally, we proposed a model of the molecular response mechanism of peach fruit at high temperature which helps to develop new approaches for maintaining fruit quality during storage.
\end{abstract}

\section{Introduction}

The purpose of commercial storage of fruit is to lengthen shelf-time and maintain the taste of pulp. The current postharvest storage technologies mainly focus on a combined utilization of storage environment factors such as temperature, modified atmosphere and chemicals, and among them temperature control is the most widely used method for fruits and vegetables during shelf life. Although cold conditioning is a virtually irreplaceable method used to prolong the postharvest quality of horticultural products, chilling injury (CI) is triggered in tropical and subtropical fruits which are sensitive to low temperature (Teklehaimanot, 2004). CI plants have a series of cellular changes, including ethylene synthesis, membrane fluidity and cytoskeletal rearrangement, resulting in internal browning (IB), flesh breakdown, lack of juiciness, and loss of flavor, which seriously affects the commercial values of fruits (Cramer et al., 2011).

With the climatic change of global warming, high temperature stress becomes a major plant stress affecting plant cellular homeostasis, crop growth and development (Tubiello et al., 2007). Plants have evolved a series of responses to raised temperature linked with heat stress proteins (HSPs), heat stress factors (HSFs), and phytohormones such as abscisic acid (ABA), salicylic acid (SA) and ethylene (Kotak et al., 2007). Besides, the effects of high temperature have been reviewed on its inhibition of ethylene production, control of postharvest diseases and reducing CI in many fruits and vegetables (Barkaigolan and Phillips, 1991; Lurie, 1998; 2005). In kiwifruit, high temperature stress controls fruit ripening by inhibiting ethylene production and signaling sensitivity (Antunes and Sfakiotakis, 2000), similar to studies on apple (Lurie and Klein, 1990) and tomato (Lurie and Klein, 1991). However, decline of fruit firmness and increase of ethylene production were observed for banana fruit during storage at high temperature (Yan et al., 2011). Overall, numerous 
studies focused on how to reduce CI and on the effect of heat treatment on ethylene metabolism, all of which showed that temperature is vital to fruit storage. However, limited studies have considered the influences of high temperature for shelf life after transient cold conditioning.

Peach (Prunus persica L. Batsch) has highly perishable fruits that decay quickly at ambient temperature. Although refrigeration is used to maintain flesh quality and prolong shelf-time, peach is highly sensitive to low temperature, resulting in CI. The major symptoms of postharvest CI are internal browning, mealiness or wooliness, and flesh bleeding or internal reddening with physiological disorders (Brummell et al., 2004; Lurie and Crisosto, 2005). In previous studies, heat treatment has been applied prior to cold storage to prevent or alleviate CI by acquiring CI tolerance in response to heat shock (Saltveit, 1991; Ferguson et al., 2000; Paull and Chen, 2000; Budde et al., 2006; Wang et al., 2006; Peng et al., 2009; Zhang et al., 2011). However, information is much less about high temperature conditioning after cold treatment in peach fruits.

In this study, we performed comparative transcriptomic analysis of postharvest peach fruits between high temperature $\left(\mathrm{HT}: 35{ }^{\circ} \mathrm{C}\right)$ and common temperature $\left(\mathrm{CT}: 25{ }^{\circ} \mathrm{C}\right)$ after a pre-storage at $5{ }^{\circ} \mathrm{C}$ for 2 days, and combined the comparison results with measured physiological changes to comprehend the process of peach fruit decay. This study provided new insights into the molecular mechanisms of temperature response during fruit shelf life and offered novel clues for developing the fruit storage technologies in practice.

\section{Materials and methods}

\section{Plant materials and treatments}

Red flesh peach (Prunus persica L. Batsch cv. Tianxianhong) (He et al., 2010) fruits with consistent color, shape and weight were harvested at commercial maturity from an orchard in Xiaogan, Hubei province, China. Uniform fruits without visual defects were selected and kept at $5{ }^{\circ} \mathrm{C}$ for 2 days after the day of harvest. Then, these fruits were randomly divided into two groups. One group was stored at CT for 7 days, and the other was stored at HT for 7 days. During shelf life, fruits were sampled at day 1, 2 and 3 as early stage as well as day 5, 6 and 7 as later stage. For each sampling point, sarcocarp was extracted and randomly distributed into two biological replicates. Then, mesocarp was sliced, frozen in liquid nitrogen and stored at $-80{ }^{\circ} \mathrm{C}$ for further study.

\section{Measurements ofphysiological changes}

Some physiological parameters were measured for each sample during storage. GY-2 fruit hardness tester with a 3.5-mm-diameter head was applied to measure the pulp firmness of fruit without peel. Six peach fruits from each sample were selected, and 7 points evenly distributed over each fruit were examined and the mean of the measured values was calculated and used. To detect ethylene production, $1 \mathrm{~kg}$ of fruits from each sample were selected and preserved in a sealed box at the same temperature for $6 \mathrm{~h}$, then $1 \mathrm{ml}$ gas sample was collected to measure ethylene production using gas chromatography (Agilent Technologies 7890A GC System, USA) with 3 biological replicates. The gas chromatographic (GC) analysis of ethylene used GC Columns $(30 \mathrm{~m} \times 0.530 \mathrm{~nm} \times 3.00 \mu \mathrm{m})$, and oven, inlet and detector temperatures were $40{ }^{\circ} \mathrm{C}, 250$ ${ }^{\circ} \mathrm{C}$ and $250{ }^{\circ} \mathrm{C}$, respectively. The ethylene standard curve was plotted with the gradients of 5 concentration values to identify the ethylene production rate. The 1-aminocyclopropane-1-carboxylic acid (ACC) synthase and ACC oxidase were extracted to measure their activities using conventional method.

\section{RNA extraction}

Total RNA was extracted from mesocarp using plant RNAOUT kit (TIANDZ, China), then the quality control of RNA was performed using 2100 Bioanalyzer system and all samples were qualified as a result. RNA samples were subjected to DNaseIdigestion (Takara, Japanese) according to instructions from the manufacturer to remove the contaminating genomic DNA. And these were purified using RNeasy MinElute Cleanup Kit (QIAGEN, Germany), and eluted with RNase-free water. Ribo-Zero Magnetic Kit (Epicentre, America) was used for depleting rRNA according to the manufacturer's protocol. Eventually, the rRNAdepleted RNA sample was used in the subsequent experiments. 


\section{RNA-Seq library construction and sequencing}

Equal amounts of total RNA for each sample was used to construct 24 RNA libraries. RNA sequencing was performed on an Illumina HiSeq 2500 platform at Chinese National Human Genome Center, Shanghai, and $100 \mathrm{bp}$ and $150 \mathrm{bp}$ paired-end reads were generated. In more detail, 24 libraries were generated using NEB Next(r) UltraTM Directional RNA Library Prep Kit for Illumina (NEB, American), and the quality, quantity and size distribution of RNA were determined using three methods: Qubit fluorometer, $2 \%$ agarose gel electrophoresis and Agilent High Sensitivity DNA Kit. The libraries were then used in cluster generation by TruSeq PE Cluster Kit (Illumina, American), and submitted for Illumina HiSeq 2500 sequencing according to the standard operation protocols. All the raw data have been uploaded to the GEO database of NCBI (accession number: GSE122868).

\section{Transcript assembly and novel transcripts annotation}

To obtain high quality data, the adapters in raw data were trimmed and the reads with low quality (Q-value $<$ 20) and shorter than 36 bp were filtered using FASTX-Toolkit (version 0.7, http://hannonlab.cshl.edu/fastx_toolkit/). The filtered FASTQ files of pair reads were justified using a custom Python script developed in our laboratory. Then, Q20, Q30 and GC content of the filtered data were calculated using FastQC (version 0.11.5, http://www.bioinformatics.babraham.ac.uk/projects/fastqc/) to confirm the quality of filtered data. All the subsequent analyses were based on the clean data with high quality. Paired-end clean reads were mapped against Prunus persica L. Batsch reference genome (prunus_persica/genome_v2.0.a1) from the genome database (GDR) (Jung et al., 2008) using Tophat (version 2.1.1) (Trapnell et al., 2009). To generate transcripts for each sample, the above results were assembled using Cufflinks suite (version 2.2.1) (Trapnell et al., 2010; Roberts et al., 2011; Trapnell et al., 2012). Novel transcripts were annotated using BLASTX (Altschul et al., 1990; Altschul et al., 1997) against the NCBI nr database and using Blast2GO (version 5) (Conesa et al., 2005) to perform InterProScan analyses. Then, the novel transcripts were annotated and categorized into 3 principal Gene Ontology (GO) categories: biological process, molecular function and cellular component (The Gene Ontology Consortium et al., 2000; The Gene Ontology Consortium, 2017). Besides, the pathway annotations were generated using SBH method in the KEGG Automatic Annotation Server (KAAS, version 2.1) (Moriya et al., 2007).

\section{Quantification of gene expression levels and differential expression analysis}

We used Cuffdiff (Trapnell et al., 2013) to calculate gene expression level as FPKM (fragments per kilobase of exon per million reads mapped) value, and generated the adjusted P-values of false discovery rate (FDR) between different conditions using the Benjamin-Hochberg method (Benjamini and Hochberg, 1995; Benjamini and Yekutieli, 2001). FPKM value of each gene was calculated. Genes with a corrected FDR of 5\% and $\mid \log _{2}$ ratio| [?] 1 were assigned as differentially expressed genes (DEGs) using R software (version 3.2.5). Wilcoxon signed rank test was used for the comparison of gene expression levels during 7 days between CT and HT conditions.

\section{Gene co-expression network analysis}

All transcripts in samples were used to perform co-expression analysis to describe the correlation patterns among genes and identify regulatory modules. Weighted gene co-expression network analysis (WGCNA) were conducted using R software package WGCNA based on expression profiles (Langfelder and Horvath, 2008). Firstly, the pairwise correlation coefficients between all genes were calculated and further transformed into adjacency matrix with a soft threshold power of 12 . To counter the effects of spurious or missing connections, topological overlap similarity was measured from the adjacency matrix (Yip and Horvath, 2007). Then, modules were detected as branches of the dendrogram using hierarchical clustering with the DynamicTreeCut algorithm and assigned to different colors(Langfelder et al., 2008). Intramodular connectivity was calculated based on the expression profiles of the module members to identify the highly connected intramodular hub genes. Besides, the correlations between gene expression profile and the phenotype measurements of interest were also calculated to explore the association of modules to external traits. Finally, Cytoscape (version 3.5.1) was used to visualize the network connections and calculate the link weights to indicate the hub-genes 
in selected modules (Shannon et al., 2003).

\section{Quantitative real-time PCR (qRT-PCR) validation}

In order to confirm the reliability and accuracy of the RNA-Seq analysis, qRT-PCR was performed on a set of 6 genes randomly selected from DEGs. Firstly, total RNA was extracted from approximately $3 g$ of frozen tissues using E.Z.N.A ${ }^{(\mathrm{r})}$. Plant RNA Kit (OMEGA, R6827) by following the producer's instructions. Genomic DNA was removed to obtain DNA-free RNA which was reversely transcribed to first-strand cDNA using PrimeScript RT reagent Kit with gDNA Eraser (TaKaRa, RR047A). Based on sequences from the peach genome database (Jung et al., 2008), gene specific primers were designed (Supplementary Table S1 ) and evaluated using NCBI Primer-BLAST (Ye et al., 2012). Translation initiation factor 1A (PpeIF-1A, ppa002870m) was used as the reference gene for data normalization according to a previous publication (Kou et al., 2017). With diluted cDNA, qRT-PCR was performed using PowerUp SYBR Green Master Mix (Thermo Fisher Scientific, A25741) on QuantStudio 6 Flex Real-Time PCR Systems (Life Technologies) with previously described primer pairs. Samples for each condition were examined in 3 technical replicates and the mean $\mathrm{Ct}$ was calculated. The $2^{-\mathrm{Ct}}$ method was used to assess the relative gene expression level between two temperature conditions at every time point.

\section{Results}

\section{Changes of firmness and ethylene production in peach fruits}

To measure the internal physiological variation in peach fruits, the changes of firmness and ethylene production were examined at 6 time points for $\mathrm{CT}$ and HT storage conditions, respectively. Interestingly, the peach fruits at HT showed a much higher level of firmness than the fruits at CT, and this was accompanied by a significantly lower level of ethylene production of $0.05 \mu \mathrm{l} / \mathrm{g} / \mathrm{h}$ in HT samples (Figure 1 ). After 3 days, firmness showed almost steady trend in both treatments. Besides, CT samples stayed in high ethylene production rate of more than $0.2 \mu \mathrm{l} / \mathrm{g} / \mathrm{h}$ on all days. These data indicated that firmness and ethylene production were correlated with each other, but ethylene may not be the only influential factor on firmness.

\section{Gene expression profiling during peach ripening and novel transcripts annotation}

To reveal the molecular responses to HT and CT in post-harvest peach fruits, samples with two biological replicates from 6 time points were processed to construct 24 RNA libraries. A total of $684 \mathrm{M}$ reads were generated with an average length of $100 \mathrm{bp}$, ranging from 10.18 to $21.57 \mathrm{M}$ raw reads per library (Supplementary Table S2 ). The reads data were pre-processed by trimming adapters and filtering out short reads $(<36 \mathrm{bp})$ and low-quality reads $(\mathrm{Q}<30)$. After pre-processing, $562 \mathrm{Mb}(82.22 \%)$ high-quality sequences were retained. The remaining paired reads were mapped to the Prunus persica reference genome, and the total mapped rate was approximately $92.26 \%$ in average (Supplementary Table S3 ).

Relative abundance of genes was calculated and normalized as FPKM, and the robustness and reproducibility of data were indicated by high Pearson correlation coefficients $(>0.97)$ among biological replicates for all comparison pairs (Supplementary Table S4 ). Besides, we identified 1,281 novel transcripts which were aligned to the reference genome but not included in the 26,873 protein-coding genes (Supplementary Data ). The lengths of those transcripts ranged from 46 to $215,643 \mathrm{bp}$, with an average length of 3,045 bp. The biological functions of novel transcripts were annotated with Gene Ontology (GO) terms by successively using BLASTx (against the NCBI database) and Blast2GO; they were also subjected to KAAS to obtain the KEGG Orthology (KO) identifiers. Finally, 353 transcripts were classified into 3 GO categories and 176 transcripts have KO annotations (Supplementary Figure S1 \& Table S5 ).

\section{Analysis of DEGs}

To identify DEGs between HT and CT conditions, the samples of each time point (day) were compared and the DEGs were detected. Firstly, we counted the expressed genes in each sample and found that peach fruits at CT underwent a more substantial decrease in the number of expressed genes compared with HT (Figure 2a $)$. A total of 7,245 DEGs $\left(P<0.05\right.$ and $\mid \log _{2}$ ratio $\mid$ [?] 1$)$ were identified in all comparison pairs between 
HT and CT. The numbers of up- and down-regulated DEGs were shown inFigure $\mathbf{2 b}$. Interestingly, there is a strong decline in the numbers of both up-regulated and down-regulated genes at ripening stage. The number of up-regulated DEGs reached summit on day 2 with 2,778 genes, showing the most significant response to $\mathrm{HT}$ in transcriptome.

Several groups of transcription factors (TFs) were identified involved in plant responses to diverse abiotic stresses including temperature and drought. Here, 301 TFs from all DEGs were identified belonging to 49 TF families. Among all the TF families, ethylene response factors (ERFs) showed the highest numbers (44) compared with others (Figure 2c ). These data suggest the important role of ERFs in high-temperature response.

GO analysis was performed to dissect the functions of DEGs. As a result, 2,665 up-regulated DEGs and 1,990 down-regulated DEGs were classified into 3 main GO categories: cellular component (CC), biological process (BP) and molecular function (MF). In up-regulated DEGs, the most abundant BP subcategories were 'nucleobase-containing compound metabolic process', 'gene expression' and 'nucleic acid metabolic process' (Figure 3a ). In down-regulated DEGs, the major BP subcategories were 'organic substance biosynthetic process', 'cellular macromolecule biosynthetic process' and 'cellular nitrogen compound biosynthetic process' (Figure 3b ). Besides, only down-regulated DEGs had enriched groups in CC and MF which are 'cytoplasm', 'structural constituent of ribosome' (Figure 3b ), etc.

\section{Mitogen-activated protein kinase (MAPK) cascades response to HT stress}

HT induces changes of cytoplasmic calcium signaling, which exerts regulatory effects on plant development and stress responses (Berridge et al., 2003; Perochon et al., 2011). Among the 7 genes of calmodulin (CALM), Prupe.3G266000 and Prupe.4G269100 showed higher transcript abundance in CT fruits, while Prupe.1G089100 was on the contrary (Figure 4a ).

The MAPK cascades are one of the major signaling pathways and highly conserved in evolution for the transformation of extracellular stimuli into intracellular responses in eukaryotic cells (Hirt, 1997; Tena et al., 2001; Zhang and Klessig, 2001; Nakagami et al., 2005). The MAPK cascades consist of three interconnected protein kinase modules: MAPK kinase kinase (MEKK), MAPK kinase (MKK), MAPK. In MAPK gene families, we found that MEKK1-MKK2-MPK4 and MPK6 had high expression levels responding to HT (Figure 4b ), which were also detected in A thalianaresponding to salt, drought and cold (Teige et al., 2004). Therefore, MEKK1-MKK2-MPK4/6 module is the most likely signaling pathway activated during HT stress.

\section{Expression of genes related to auxin biosynthesis, transport and signaling}

Tryptophan (Trp) is a precursor for auxin (indole-3-acetic acid, IAA) (Woodward and Bartel, 2005), whose related genes were shown to be differentially expressed under CT and HT in post-harvest peach fruits. Although the expression level of tryptophan synthase alpha chain (TRPA; Prupe.3G144500) was decreased on day 2 in both treatments (Figure 5 ), the expression level of tryptophan synthase beta chain (TRPB; Prupe.4G207900) showed a peak on day 2 and reached the maximum on day 7 for the CT condition but not for the HT condition. The expression level of another auxin biosynthetic enzyme, indole-3-glycerol phosphate synthase (IGPS; Prupe.3G196200), manifested different trends between HT and CT at early stage. Overall, HT reduces tryptophan biosynthetic enzyme expression level compared with CT.

Several Trp-dependent pathways, which are generally named after an intermediate, have been proposed, including indole-3-pyruvic acid (IPA) pathway, indole-3-acetamide (IAM) pathway, tryptamine (TAM) pathway and indole-3-acetaldoxime (IAOx) pathway (Woodward and Bartel, 2005; Zhao, 2012). In IPA pathway [Trp - IPA - IAA], the FPKM value of tryptophan aminotransferase of Arabidopsis(TAA1) was less than 5 in all samples, but the expression of indole-3-pyruvate monooxygenase (YUCCA) significantly increased on day 2 at HT. In IAM pathway [Trp - IAM - IAA], the amidase (AMI; Prupe.6G327700) had increased expression at the early stage under both temperatures. In TAM pathway [Trp - TAM - indole-3-acetaldehyde (IAAld) - IAA], aldehyde dehydrogenase (NAD+) (ALDH2B7; Prupe.1G255200) under HT showed lower expression 
than CT in the whole storage period. To sum up, IPA pathway is affected most by HT in our work.

The expression patterns of auxin-related genes were evaluated to understand their responses to HT. It was found that the expression of auxin influx carrier 1 (AUX1) decreased most on day 2 (Figure 5 ) under both temperature conditions, but auxin efflux carrier component (Pin-formed, PIN5) had a higher expression level under CT. The auxin response factor (ARF) genes in group II increased at the later stage for CT rather than HT condition (Supplementary Figure S2 ).

These auxin-responsive genes have been classified into three major groups: Aux/IAA, small auxin-up RNA (SAUR), and Gretchen Hagen 3 (GH3) (Guilfoyle, 1999; Liscum and Reed, 2002). Aux/IAAs were sorted into three groups based on cluster analysis (Figure 6 ), which bind transcription factors of ARF family (Supplementary Figure S2 ). Generally, the genes within Group I were down-regulated with time, while the genes in Group III showed a higher level of expression in HT fruits (Figure 6 ). Based on the clustering results, SAUR genes were divided into four groups which had different responses to CT and HT (Supplementary Figure S3 ). In addition, the gene GH3.1 (Prupe.6G226100) showed a higher expression level under CT compared with HT, while the other three members of GH3 gene family (GH3.6, Prupe.8G248400; GH3.1, Prupe.8G137900; GH3.17, Prupe.1G213200) showed higher expression levels under $\mathrm{CT}$ in the later stage (Figure $\mathbf{5}$ ).

\section{Expression of genes related to ethylene biosynthesis and signaling pathway}

Ethylene is biosynthesized by S-adenosylmethionine synthetase (SAMS) from the amino acid methionine to S-adenosyl-L-methionine (SAM), and SAM is then converted by 1-aminocyclopropane-1-carboxylic acid (ACC) synthase (ACS) to ACC which is further catalyzed by ACC-oxidase (ACO) to ethylene. Notably, the activity of ACS determines the rate of ethylene production (Yu et al., 1979). Similar to ethylene production (Figure 1b ), the peach fruits at $\mathrm{CT}$ were higher than $\mathrm{HT}$ in the enzyme activities of ACO and ACS at most time points (Figure 7 ).

Expressions of genes involved in ethylene biosynthesis and signaling were examined to understand the lower ethylene production in HT fruits. Among these, the expression of 5 genes (SAMS5, Prupe.1G107000; SAMS1, Prupe.3G004000; SAMS3, Prupe.7G128500; ACS1, Prupe.2G176900; ACO1, Prupe.3G209900) were significantly higher at CT than HT (Figure 8a), which agreed with the physiological data of ACO/ACS activities (Figure 7 ).

Ethylene is perceived by a family of five membrane-localized receptors that are homologous to bacterial two-component histidine kinases involved in sensing environmental changes (Stepanova and Alonso, 2009). According to the homology with Arabidopsis, four peach ethylene receptors were identified, including ethylene receptors 1 (ETR1; Prupe.1G556000), ETR2 (Prupe.1G034300), ethylene response sensor 1 (ERS1; Prupe.8G265200) and ethylene insensitive 4 (EIN4; Prupe.6G348000). The expression levels of ETR2 and ERS1 at CT were generally higher than HT, while those of ETR1 and EIN4 were not obvious (Figure 8b ). Constitutive triple response 1 (CTR1; Prupe.7G117700), the downstream element of ethylene receptors, showed significantly decreased expression on day 2 with an average of 2.69-fold change, and then kept in low FPKM value at later time points (Figure 8b ). Especially, EIN2 (Prupe.6G235600), whose function is a positive regulator of the ethylene pathway (Stepanova and Alonso, 2009), displayed reverse trends of expression levels between CT and HT. EIN3 (Prupe.2G058500, Prupe.2G058400) exhibited declining expression level on day 2. Besides, ERFs were sorted into four groups based on hierarchical clustering (Supplementary Figure S4a ). Group I showed a higher level of transcripts in HT condition, indicating that group I genes might play a significant role in heat stress response (Supplementary Figure S4b ). Therefore, temperature caused complicated responses in receptor genes and downstream signaling genes of ethylene in both CT and HT conditions.

\section{Expression of genes related to}

\section{flesh softening}

The enzymes involved in cell wall reconstruction are the key factors for keeping cell shape and maintaining me- 
chanical strength of peach fruits (Hayama et al., 2006). We found that 5 genes had higher FPKM values in CT fruits, including beta-glucosidase (BGlu), polygalacturonase (PG, Prupe.4G261900 and Prupe.4G262200), pectate lyase (PLY) and pectin methylesterase (PME) (Supplementary Figure S5 ). The mean FPKM value of PG (Prupe.4G262200) was 6,359.39, significantly higher than other genes $(P$-value $<0.01)$. Notably, PG (Prupe.4G261900), PLY (Prupe.1G239900) and PME (Prupe.7G192800) displayed a markedly distinct expression pattern that HT treated fruits had extremely low expression levels at all time points. Expansin protein (EXP) is connected with cell enlargement and cell wall change induced by plant hormones such as gibberellin, cytokinin, ethylene and brassinosteroids (Sampedro and Cosgrove, 2005). We found that EXP2 (Prupe.1G276700) had nearly constant expression levels at all time points in HT condition, and EXP1 (Prupe.2G263600) had opposite responses to CT and HT in transcriptional level during storage. Overall, these genes cooperate to prevent flesh softening in HT.

\section{Expression of genes related toenzymatic browning}

Enzymatic browning impairs the sensory properties of fruits such as color and flavor, as a result of oxidative polymerization of phenolic compounds catalyzed by polyphenol oxidase (PPO) and peroxidase (POD) (Nicolas et al., 1994). Besides, the relationships between fruit browning and antioxidant enzymes such as lipoxygenase (LOX, EC 1.13.11.12), superoxide dismutase (SOD, EC 1.15.1.1) and catalase (CAT, EC 1.11.1.6), have been reported previously (Inzé and Montagu, 1995). There is no obvious trend in mRNA levels of POD genes during shelf life, while two genes (Prupe.1G29900, Prupe.3G278900) were up-regulated in CT condition, contrary to Prupe.4G042100 (PPO), Prupe.4G021100 (POD) and Prupe.2G005300 (LOX) (Supplementary Figure S6 ). Particularly, the expression levels of SOD1 and SOD2 were increased at the middle stage in CT condition and mostly higher than HT condition. Enzymatic browning is a strong and complex response to HT according to our research.

\section{Correlation between co-expression modules and physiological changes}

The expression data and traits data of all samples were used in Weighted Gene Coexpression Network Analysis (WGCNA) and the relationships between them were visualized (Supplementary Figure S7 ). By using hierarchical clustering and dynamic tree cut method, co-expression modules were obtained (Supplementary Figure S8 ); after merging and filtering, a total of 28 modules remained; among them, the largest module (MEpaleturquoise) contains 2,691 genes while the smallest module (MEdarkorange2) only includes 181 genes (Supplementary Table S6 ).

The relationships between modules and physiological traits were examined (Figure 9 ). Firmness showed high correlation with the expression levels of genes from MEdarkorange2 and MEdarkred modules $(R>$ $0.7)$ and anti-correlation with those from MElightyellow, MEdarkgrey and MEbrown4 modules $(R<-0.7)$. Ethylene production was significantly correlated with six modules $(P<0.01)$, including MEsaddlebrown, MElightgreen, MEbisque4, MElightsteelblue1, MEskyblue3 and MEpaleturquoise. MEskyblue3 module was positively correlated with LOX2 $(R=0.86)$ but negatively correlated with ASA $(R=-0.7)$. MEgrey module had no significant $(P<0.05)$ correlation with all physiological changes. Notably, the levels of AAO, AMS, LOX2, $\mathrm{O}_{2}^{-}$and $\beta$-Gal displayed similar correlations with ethylene in many modules.

To further explore the biological function of each module, GO annotation and enrichment analysis were performed. As shown (Supplementary Figure S9 ), MEdarkgrey module was enriched in the GO term of endopeptidase Clp complex in cellular component category; MEskyblue3 module was enriched in the GO term of amino acid kinase activity; MElightyellow module was enriched in catalytic activity in molecular function category. Moreover, the sub-network involving all the above genes was extracted from the whole coexpression network (Supplementary Figure S10 ). The sub-network is roughly parted into two clusters: the cluster in the upper side contains genes mostly from MEskybule module and the cluster in the lower side contains genes from other modules. The genes AUX/IAA, SAUR and SAMS3 from the bisque4 module had high degrees in the sub-network, indicating that they played key roles in the correlations with other modules.

\section{Confirmation of DEGs by qRT-PCR}


To validate the RNA-Seq data, six genes were randomly selected from the peach fruit DEGs for qRTPCR analysis using PpeIF-1A as the internal control gene. The ratio of gene expression levels between $\mathrm{CT}$ and HT at each time point were calculated for both the RNA-Seq and qRT-PCR experiments. As shown in Supplementary Figure S11, the fold-changes in base-2 logarithm were similar between the two technologies, which confirmed the reliability of our transcriptome measurement.

\section{Discussion}

Peach fruits are usually harvested in hot summer, and in transport, softening, decay and browning are accelerated. Responses to high temperature during fruit ripening and senescence involve a series of physiological and molecular changes. Little information is available on the transcriptomic responses to high temperature in postharvest peach fruits. Here, HT conditioning after cold treatment was performed and it showed beneficial effects to the 'Tianxianhong' peach fruits (flesh firmness without cold injury). The factors affecting fruit quality during storage were identified as ethylene metabolism, cell wall enzymes and cellular oxidase which showed different responses to high temperature. We summarized our transcriptomic findings into a rough model for the high temperature response process in peach fruits (Figure 10 ). First, MEKK1MKK2-MPK4/6 are highly expressed, which was regarded as the stress signal transduction process following HT. Then, the low expression levels of ACS1 and ACO reduced biosynthesis of ethylene and the decreased expression of TRPB, IGPS and ALDH2B7 reduced auxin production. A series of genes involved in flesh softening and membrane stability were influenced by these response factors such as ARFs, GH3 and ERFs. Finally, fruit quality in storage was improved under HT.

MAPK cascades play a key role in various cellular processes with accurate signal transduction via phosphorylation of their substrate proteins (Ichimura et al., 2002). In plants, MAPKs have been identified in abiotic stress and hormonal responses, innate immunity, disease resistance and developmental programs (Cristina et al., 2010). Among them, abiotic stress induction of MAPK genes and increased MAPK kinase activity have been detected when plants are subjected to salt, drought, cold, ozone and oxidative stresses (Mizoguchi et al., 1996), but there have been few studies of the MAPKs under high temperature stress in plants. In our study, the MEKK1-MKK2-MPK4/6 displayed high transcript abundances under HT. This is similar to the findings in the research of plant MAPK signaling during abiotic stress. In A. thaliana, MKK2 plays a pivotal role in cold and salt stress responses following the stress-induced MEKK1 and followed by the downstream MAPK4 and MAPK6 (Teige et al., 2004). MAPK4 and MAPK6 are also rapidly activated by wounding and touch associated with tyrosine phosphorylation (Ichimura et al., 2002). In addition, high temperature up-regulates the expression of MPK6 and AtMPK6-phosphorylated HSFA2 might participate in the response in A. thaliana ( $\mathrm{Li}$ et al., 2012b). While in tomato, SIMPK1, a close homolog to AtMPK6, showed a negative effect on thermotolerance by regulating antioxidant defense via its substrate SISPRH1 involved in this pathway (Ding et al., 2018). To sum up, these data identified that the MEKK1-MKK2MPK4/6 cascades mediate high temperature response in peach. Analyzing loss and over-expression of these genes in peach fruit would help to determine their potential effects in HT stress.

Ethylene is a major plant hormone involved in the regulation of many fruit developmental processes from maturation to ripening and senescence (Bapat et al., 2010; Pech et al., 2012; Kumar et al., 2014) . It was identified as a trigger and promoter in typical climacteric fruits ripening and can crosstalk to other phytohormones including auxin (Aux), ABA, jasmonic acid (JA) through controlling their biosynthesis pathway and signaling pathway (Kumar et al., 2014). However, there are few studies on the effect of temperature on ethylene metabolism and the corresponding molecular mechanism. In our study, the expression levels of ACO and ACS genes and their enzyme activities were both decreased in HT samples, resulting in lower ethylene production than CT fruits, which indicated that the ethylene biosynthesis that is affected by heat stress plays an important role in peach fruit ripening process. Similarly, in grapevine berry, ACO and ACS genes were also less expressed under the high temperature regime of $41.7^{\circ} \mathrm{C}$ (the maximum air temperature) (Pastore et al., 2017). In Kiwifruit, fruit ripening was inhibited by decreased ACS and ACO activities at high temperature above $30{ }^{\circ} \mathrm{C}$ (Antunes and Sfakiotakis, 2000). These showed that temperature has direct effect on the process of ethylene biosynthesis especially on its ACO and ACS enzymes. But what exact 
reason the maturity inhibition effect is attributed to has not been determined; for example, it can be a lack of ethylene production, the inability to react to ethylene, or other reasons (Burg, 1962). EIN3 and ERFs, the downstream elements of ethylene signaling pathway, play important roles in development, defense, and environment related responses in fruits (Gutterson and Reuber, 2004; Mizoi et al., 2012; Licausi et al., 2013). The ERF proteins, specifically binding to an AGCCGCC element (GCC box), were found in the promoter region of ethylene-regulated genes and could respond to ethylene, pathogens, and wounding (Ohme-takagi and Shinshi, 1995). In this study, the expression levels of ERFs under HT condition were clustered into several groups (Supplementary Figure S4) and co-expressed with several genes related to membrane oxidation and cell wall metabolism (Supplementary Figure S10 ). In Arabidopsis, ERF genes were involved in cell expansion which requires the proteins EXP and the actin modeling factor ADF5 (MarschMartinez et al., 2006), and also link to ethylene signaling and auxin biosynthesis (Mao et al., 2016). Ethylene response element binding protein (EREBP, Prupe.1G432000) in group II (Supplementary Figure S4 ) was co-expressed with PE, POD and AUX genes in peach fruits, and its ortholog APD1(AT4G13040.1) in Arabidopsis has been reported as an important regulator for basal plant defense and abiotic stress response (Giri et al., 2014). This raises a possibility that several downstream genes associated with flesh softening and membrane oxidation could be involved in the ERFs response to heat stress. Clarifying the relationship between them should be a goal of future work on heat response.

It has been reported that MAPK cascades regulate ethylene biosynthesis and signal transduction by protein phosphorylation and the expression of ACS genes (Meng and Zhang, 2013; Li et al., 2017). ACS proteins are substrates of MPK3 and MPK6, and the phosphorylation of ACS results in an increase in ethylene production in tobacco and Arabidopsis(Liu and Zhang, 2004; Han et al., 2010; Li et al., 2012a). In our results, the expression of MAPK4 and MAPK6 were induced by high temperature at early stage (Figure 4b ) and meanwhile low ACS1 expression and ethylene production were observed. This implies the potential association between MAPK cascades and ACS genes in peach fruits, which needs further experimental verification.

In summary, we proposed a model of the molecular response mechanism of peach fruit at high temperature: under HT condition, MAPK cascade acts as a signal sensor and triggers the down-regulation of ethylene production and auxin synthesis; ERF/ARF proteins regulate cell wall enzymes and membrane enzymes; these processes ultimately help to maintain fruit quality. A series of direct or indirect possible regulations are proposed in the model, such as ACS1/ACO for ethylene production and EXP for fruit hardness. Future validation of these regulations will enhance our understanding on the high temperature response of fruits. The findings of this study provide new insights into the molecular mechanism of temperature adaptation and have implications for high temperature domestication of fruits.

\section{Author Contributions}

Conceived and designed the experiments: B.G.M., C.A.L. Performed the experiments: X.W., K.L.C., Z.H.T., B.Z.W. Analyzed the data: X.W., B.Z.W., B.G.M. Wrote the paper: X.W., B.Z.W., B.G.M. Revised the paper: C.A.L.

\section{Funding}

This work was supported by the National Basic Research Program of China (973 Program, Grant 2013CB127103), the National Natural Science Foundation of China (Grant NO. 31570844) and the National Natural Science Foundation of China (Grant NO. 31672205).

\section{Acknowledgments}

Helpful discussion with Ling-Ge Niu is appreciated.

\section{Conflict of Interest}

The authors declare that the research was conducted in the absence of any commercial or financial relationships that could be construed as a potential conflict of interest. 


\section{Data availability statements}

The datasets analyzed for this study can be found in the GEO database of NCBI (accession number: GSE122868).

\section{Supplementary Materials}

Supplementary data associated with this article can be found in the online version

\section{Figure Legends}

Figure 1. Firmness and ethylene production in peach fruit after harvest during shelf life. (a) Flesh firmness. (b) Ethylene production rate. Peach fruits were primarily held at $5 \operatorname{degC}$ for 2 days and then stored at 25 $\operatorname{deg} \mathrm{C}$ or $35 \operatorname{deg} \mathrm{C}$ for $7 \mathrm{~d}$. P-values indicated the significance of difference between $\mathrm{HT}$ and CT which were calculated by Wilcoxon signed rank test. HT, high temperature (35 degC); CT, common temperature $(25$ $\operatorname{deg} \mathrm{C})$.

Figure 2. Overview of gene expression differences between HT and CT. (a) Number of genes expressed during shelf life. (b) Number of DEGs identified between HT and CT at each time point (adjusted-P < 0.05). (c) The number of DEGs in TF family. Up, up-regulated; Down, down-regulated; HT, high temperature; CT, common temperature; DEGs, differentially expressed genes.

Figure 3. GO enrichment of differentially expressed genes. (a) GO enrichment of up-regulated DEGs. (b) GO enrichment of down-regulated DEGs. HT, high temperature; CT, common temperature; DEGs, differentially expressed genes.

Figure 4. Expression profiles of CALMs (a) and MAPKs (b) genes. P-values indicated the significance of difference between HT and CT which were calculated by Wilcoxon signed rank test. HT, high temperature; CT, common temperature; FPKM, fragments per kilobase of exon per million reads mapped; CALM, calmodulin; MAPK, mitogen-activated protein kinase.

Figure 5. Expression profiles of genes related to auxin biosynthesis, transport and signaling. P-values indicated the significance of difference between HT and CT which were calculated by Wilcoxon signed rank test. HT, high temperature; CT, common temperature; FPKM, fragments per kilobase of exon per million reads mapped; TRPA, tryptophan synthase alpha chain; TRPB, tryptophan synthase beta chain; IGPS, indole-3-glycerol phosphate synthase; YUCCA, indole-3-pyruvate monooxygenase; AMI, amidase; ALDH, aldehyde dehydrogenase (NAD+); AUX1, auxin influx carrier; TIR, transport inhibitor response.

Figure 6. Aux/IAA clustering in HT and CI fruits. (a) Clustering of expression profiles of Aux/IAA genes. The color from green to red means the expression level from low to high. (b) The average expression level of genes in each clustering group during HT and CT storage. HT, high temperature; CT, common temperature; FPKM, fragments per kilobase of exon per million reads mapped.

Figure 7. Enzymatic activity changes in peach fruit during different temperature shelf life. (a) ACO, 1-aminocyclopropane-1-carboxylic acid oxidase. (b) ACS, 1-aminocyclopropane-1-carboxylic acid synthase. P-values indicated the significance of difference between HT and CT which were calculated by Wilcoxon signed rank test. HT, high temperature; CT, common temperature.

Figure 8. Expression profiles of genes related to (a) ethylene biosynthesis and (b) signaling pathway. Pvalues indicated the significance of difference between HT and CT which were calculated by Wilcoxon signed rank test. HT, high temperature; CT, common temperature; FPKM, fragments per kilobase of exon per million reads mapped; SAMS, S-adenosylmethionine synthetase; ACO, 1-aminocyclopropane-1-carboxylic acid oxidase; ACS, 1-aminocyclopropane-1-carboxylic acid synthase; ETR, ethylene receptor; ERS, ethylene response sensor; EIN, ethylene insensitive; CTR, constitutive triple response; SIMKK, mitogen-activated protein kinase kinase; EBF, EIN3-binding F-box protein. 
Figure 9. Relationship between modules and physiological traits. The correlation coefficient $\mathrm{R}$ and the corresponding P-value (in parenthesis) are shown in each grid. The color in heatmap from blue to red means the correlation coefficient from negative (-1) to positive (1).

Figure 10. A proposed model for postharvest peach fruit response to high temperature. Red color indicates positive effect and green color indicates the opposite.

\section{References}

Alexander, L., and Grierson, D. (2002). Ethylene biosynthesis and action in tomato: a model for climacteric fruit ripening. Journal of experimental botany53(377), 2039-2055. doi: 10.1093/jxb/erf072

Altschul, S.F., Gish, W., Miller, W., Myers, E.W., and Lipman, D.J. (1990). Basic local alignment search tool.Journal of Molecular Biology 215(3), 403-410. doi: 10.1016/S0022-2836(05)80360-2.

Altschul, S.F., Madden, T.L., Schaffer, A.A., Zhang, J.H., Zhang, Z., Miller, W., et al. (1997). Gapped BLAST and PSI-BLAST: a new generation of protein database search programs. Nucleic Acids Research 25(17), 3389-3402. doi: 10.1093/nar/25.17.3389.

Antunes, M.D.C., and Sfakiotakis, E.M. (2000). Effect of high temperature stress on ethylene biosynthesis, respiration and ripening of 'Hayward' kiwifruit. Postharvest Biology and Technology 20(3), 251-259. doi: 10.1016/S0925-5214(00)00136-8

Bapat, V.A., Trivedi, P.K., Ghosh, A., Sane, V.A., Ganapathi, T.R., and Nath, P. (2010). Ripening of fleshy fruit: Molecular insight and the role of ethylene. Biotechnology Advances 28(1), 94-107. doi: 10.1016/j.biotechadv.2009.10.002.

Barkaigolan, R., and Phillips, D.J. (1991). Postharvest heat treatment of fresh fruits and vegetables for decay control. Plant Disease 75(11), 1085.

Benjamini, Y., and Hochberg, Y. (1995). Controlling the False Discovery Rate: A Practical and Powerful Approach to Multiple Testing. Journal of the Royal Statistical Society 57(1), 289-300.

Benjamini, Y., and Yekutieli, D. (2001). The Control of the False Discovery Rate in Multiple Testing under Dependency. Annals of Statistics 29(4), 1165-1188.

Berridge, M.J., Bootman, M.D., and Roderick, H.L. (2003). Calcium signalling: Dynamics, homeostasis and remodelling. Nature Reviews Molecular Cell Biology 4(7),517-529. doi: 10.1038/nrm1155.

Brummell, D.A., Dal Cin, V., Lurie, S., Crisosto, C.H., and Labavitch, J.M. (2004). Cell wall metabolism during the development of chilling injury in cold-stored peach fruit: association of mealiness with arrested disassembly of cell wall pectins. Journal of experimental botany 55(405), 2041-2052. doi: 10.1093/jxb/erh228.

Budde, C.O., Polenta, G., Lucangeli, C.D., and Murray, R.E. (2006). Air and immersion heat treatments affect ethylene production and organoleptic quality of 'Dixiland' peaches.Postharvest Biology 83 Technology 41(1), 32-37. doi: 10.1016/j.postharvbio.2006.02.009.

Burg, S.P. (1962). The Physiology of Ethylene Formation. Annual Review of Plant Physiology13(1), 265-302. doi: 10.1146/annurev.pp.13.060162.001405.

Conesa, A., Gotz, S., Garcia-Gomez, J.M., Terol, J., Talon, M., and Robles, M. (2005). Blast2GO: a universal tool for annotation, visualization and analysis in functional genomics research. Bioinformatics 21(18), 3674-3676. doi: 10.1093/bioinformatics/bti610.

Cramer, G.R., Kaoru, U., Serge, D., Mario, P., and Kazuo, S. (2011). Effects of abiotic stress on plants: a systems biology perspective. Bmc Plant Biology 11(1),163.

Cristina, M., Petersen, M., and Mundy, J. (2010). Mitogen-Activated Protein Kinase Signaling in Plants.Annual Review of Plant Biology 61(1), 621-649. doi: 10.1146/annurev-arplant-042809-112252. 
Ding, H., He, J., Wu, Y., Wu, X., Ge, C., Wang, Y., et al. (2018). The Tomato Mitogen-Activated Protein Kinase SlMPK1 Is as a Negative Regulator of the High-Temperature Stress Response. Plant Physiology 177(2), 633-651. doi: 10.1104/pp.18.00067.

Ferguson, I.B., Ben-Yehoshua, S., Mitcham, E.J., Mcdonald, R.E., and Lurie, S. (2000). Postharvest heat treatments: introduction and workshop summary. Postharvest Biology \& Technology 21(1), 1-6.

Giri, M.K., Swain, S., Gautam, J.K., Singh, S., Singh, N., Bhattacharjee, L., et al. (2014). The Arabidopsis thaliana At4g13040 gene, a unique member of the AP2/EREBP family, is a positive regulator for salicylic acid accumulation and basal defense against bacterial pathogens. Journal of Plant Physiology171(10), 860-867. doi: 10.1016/j.jplph.2013.12.015.

Guilfoyle, T.J. (1999). Chapter 19 - Auxin-regulated genes and promoters. New Comprehensive Biochemistry 33, 423-459.

Gutterson, N., and Reuber, T.L. (2004). Regulation of disease resistance pathways by AP2/ERF transcription factors. Current Opinion in Plant Biology7(4), 465-471. doi: 10.1016/j.pbi.2004.04.007.

Han, L., Li, G.-J., Yang, K.-Y., Mao, G., Wang, R., Liu, Y., et al. (2010). Mitogen-activated protein kinase 3 and 6 regulate Botrytis cinerea-induced ethylene production in Arabidopsis. The Plant Journal 64(1), 114-127. doi: doi:10.1111/j.1365-313X.2010.04318.x.

Hayama, H., Shimada, T., Fujii, H., Ito, A., and Kashimura, Y. (2006). Ethylene-regulation of fruit softening and softening-related genes in peach. Journal of Experimental Botany 57(15), 4071-4077. doi: $10.1093 / \mathrm{jxb} / \mathrm{erl} 178$

He, H.P., Gong, L.Z., Wang, F.R., Gu, X., and Wang, H.L. (2010). Tianxianhong, a new red-fleshed peach cultivar. Journal of Fruit Science 27(1), 150-145.

Hirt, H. (1997). Multiple roles of MAP kinases in plant signal transduction. Trends in Plant Science2(1), 11-15. doi: 10.1016/S1360-1385(96)10048-0

Ichimura, K., Shinozaki, K., Tena, G., Sheen, J., Henry, Y., Champion, A., et al. (2002). Mitogen-activated protein kinase cascades in plants: A new nomenclature. Trends in Plant Science 7(7), 301-308. doi: 10.1016/S1360-1385(02)02302-6.

Inze, D., and Montagu, M.V. (1995). Oxidative stress in plants. Current Opinion in Biotechnology6(2), 153-158. doi: 10.1016/0958-1669(95)80024-7.

Jung, S., Staton, M., Lee, T., Blenda, A., Svancara, R., Abbott, A., et al. (2008). GDR (Genome Database for Rosaceae): integrated web-database for Rosaceae genomics and genetics data. Nucleic Acids Research 36(suppl_1),D1034-D1040. doi: 10.1093/nar/gkm803.

Kotak, S., Larkindale, J., Lee, U., von Koskull-Doring, P., Vierling, E., and Scharf, K.D. (2007). Complexity of the heat stress response in plants. Current Opinion in Plant Biology 10(3), 310-316. doi: 10.1016/j.pbi.2007.04.011.

Kou, X., Zhang, L., Yang, S., Li, G., and Ye, J. (2017). Selection and validation of reference genes for quantitative RT-PCR analysis in peach fruit under different experimental conditions. Scientia Horticulturae 225, 195-203.

Kumar, R., Khurana, A., and Sharma, A.K. (2014). Role of plant hormones and their interplay in development and ripening of fleshy fruits. Journal of Experimental Botany65(16), 4561-4575. doi: $10.1093 / \mathrm{jxb} / \mathrm{eru} 277$.

Langfelder, P., and Horvath, S. (2008). WGCNA: An R package for weighted correlation network analysis.BMC Bioinformatics 9, 559. doi: 10.1186/1471-2105-9-559. 
Langfelder, P., Zhang, B., and Horvath, S. (2008). Defining clusters from a hierarchical cluster tree: The Dynamic Tree Cut package for R. Bioinformatics24(5), 719-720. doi: 10.1093/bioinformatics/btm563.

Li, G., Meng, X., Wang, R., Mao, G., Han, L., Liu, Y., et al. (2012a). Dual-level regulation of ACC synthase activity by MPK3/MPK6 cascade and its downstream WRKY transcription factor during ethylene induction in Arabidopsis. PLoS genetics8(6), e1002767-e1002767. doi: 10.1371/journal.pgen.1002767.

Li, J., Tao, X., Bu, J., Ying, T., Mao, L., and Luo, Z. (2017). Global transcriptome profiling analysis of ethylene-auxin interaction during tomato fruit ripening.Postharvest Biology and Technology 130(April), 28-38. doi: 10.1016/j.postharvbio.2017.03.021.

Li, Z., Yue, H., and Xing, D. (2012b). MAP Kinase 6-mediated activation of vacuolar processing enzyme modulates heat shock-induced programmed cell death in Arabidopsis.New Phytologist 195(1), 85-96. doi: 10.1111/j.1469-8137.2012.04131.x.

Licausi, F., Ohme-Takagi, M., and Perata, P. (2013). APETALA2/Ethylene Responsive Factor (AP2/ERF) transcription factors: mediators of stress responses and developmental programs. The New phytologist 199(3), 639-649. doi: 10.1111/nph.12291.

Liscum, E., and Reed, J.W. (2002). Genetics of Aux/IAA and ARF action in plant growth and development.Plant Molecular Biology 49(3-4), 387-400.

Liu, Y., and Zhang, S. (2004). Phosphorylation of 1-aminocyclopropane-1-carboxylic acid synthase by MPK6, a stress-responsive mitogen-activated protein kinase, induces ethylene biosynthesis in Arabidopsis. Plant Cell 16(12),3386-3399. doi: 10.1105/tpc.104.026609.

Lurie, S. (1998). Postharvest heat treatments. Postharvest Biology $\&$ Technology 14(3),257-269.

Lurie, S. (2005). Heat Treatments to Reduce Chilling Injury and Superficial Scald. doi: 10.1201/9780203500361.ch3.

Lurie, S., and Crisosto, C.H. (2005). Chilling injury in peach and nectarine. Postharvest Biology and Technology 37(3), 195-208. doi: 10.1016/j.postharvbio.2005.04.012.

Lurie, S., and Klein, J.D. (1990). Heat treatment of ripening apples: differential effects on physiology and biochemistry. Physiologia Plantarum 78(2), 181-186. doi: 10.1111/j.1399-3054.1990.tb02078.x.

Lurie, S., and Klein, J.D. (1991). Acquisition of Low-temperature Tolerance in Tomatoes by Exposure to High-temperature Stress. Journal of the American Society for Horticultural Science 116(6), 1007-1012.

Mao, J.-L., Miao, Z.-Q., Wang, Z., Yu, L.-H., Cai, X.-T., and Xiang, C.-B. (2016). Arabidopsis ERF1 Mediates Cross-Talk between Ethylene and Auxin Biosynthesis during Primary Root Elongation by Regulating ASA1 Expression. PLoS genetics 12(1), e1005760-e1005760. doi: 10.1371/journal.pgen.1005760.

Marsch-Martinez, N., Greco, R., Becker, J.D., Dixit, S., Bergervoet, J.H.W., Karaba, A., et al. (2006). BOLITA, an Arabidopsis AP2/ERF-like transcription factor that affects cell expansion and proliferation/differentiation pathways. Plant Molecular Biology 62(6), 825-843. doi: 10.1007/s11103-006-9059-1.

Meng, X., and Zhang, S. (2013). MAPK Cascades in Plant Disease Resistance Signaling. Annual Review of Phytopathology 51(1), 245-266. doi: 10.1146/annurev-phyto-082712-102314.

Mizoguchi, T., Irie, K., Hirayama, T., Hayashida, N., Yamaguchishinozaki, K., Matsumoto, K., et al. (1996). A gene encoding a mitogen-activated protein kinase kinase kinase is induced simultaneously with genes for a mitogen-activated protein kinase and an S6 ribosomal protein kinase by touch, cold, and water stress in Arabidopsis thaliana. Proceedings of the National Academy of Sciences 93(2), 765-769. doi: 10.1073/pnas.93.2.765.

Mizoi, J., Shinozaki, K., and Yamaguchi-Shinozaki, K. (2012). AP2/ERF family transcription factors in plant abiotic stress responses. Biochimica et Biophysica Acta1819(2), 86-96. doi: 10.1016/j.bbagrm.2011.08.004. 
Moriya, Y., Itoh, M., Okuda, S., Yoshizawa, A.C., and Kanehisa, M. (2007). KAAS: an automatic genome annotation and pathway reconstruction server. Nucleic Acids Research 35, W182-W185. doi: 10.1093/nar/gkm321.

Nakagami, H., Pitzschke, A., and Hirt, H. (2005). Emerging MAP kinase pathways in plant stress signalling. Trends in Plant Science 10(7), 339-346. doi: 10.1016/j.tplants.2005.05.009.

Nicolas, J.J., Richard-Forget, F.C., Goupy, P.M., Amiot, M.J., and Aubert, S.Y. (1994). Enzymatic browning reactions in apple and apple products. Crit Rev Food Sci Nutr34(2), 109-157. doi: 10.1080/10408399409527653.

Ohme-takagi, M., and Shinshi, H. (1995). Ethylene-lnducible DNA Binding Proteins That lnteract with an Ethylene-Responsive Element. 7(February), 173-182.

Pastore, C., Dal Santo, S., Zenoni, S., Movahed, N., Allegro, G., Valentini, G., et al. (2017). Whole Plant Temperature Manipulation Affects Flavonoid Metabolism and the Transcriptome of Grapevine Berries. Frontiers in Plant Science8(June), 1-16. doi: 10.3389/fpls.2017.00929.

Paull, R.E., and Chen, N.J. (2000). Heat treatment and fruit ripening. Postharvest Biology 83 Technology 21(1), 21-37.

Pech, J.-C., Purgatto, E., Bouzayen, M., and Latche, A. (2012). Ethylene and Fruit Ripening. 275-304. doi: 10.1002/9781118223086.ch11.

Peng, J., Zheng, Y.H., Tang, S.S., Rui, H.J., and Wang, C.Y. (2009). A combination of hot air and methyl jasmonate vapor treatment alleviates chilling injury of peach fruit.Postharvest Biology $8 \mathcal{G}$ Technology 52(1), 24-29.

Perochon, A., Aldon, D., Galaud, J.-P., and Ranty, B. (2011). Calmodulin and calmodulin-like proteins in plant calcium signaling. Biochimie 93(12), 2048-2053. doi: https://doi.org/10.1016/j.biochi.2011.07.012.

Roberts, A., Trapnell, C., Donaghey, J., Rinn, J.L., and Pachter, L. (2011). Improving RNA-Seq expression estimates by correcting for fragment bias. Genome Biology12(3), R22. doi: 10.1186/gb-2011-12-3-r22.

Saltveit, M. (1991). Prior temperature exposure affects subsequent chilling sensitivity.Physiologia Plantarum 82(4), 529-536. doi: 10.1111/j.1399-3054.1991.tb02943.x.

Sampedro, J., and Cosgrove, D.J. (2005). The expansin superfamily. Genome Biology 6(12),242-242. doi: 10.1186/gb-2005-6-12-242.

Shannon, P., Markiel, A., Owen, O., Baliga, N.S., Wang, J.T., Ramage, D., et al. (2003). Cytoscape: a software environment for integrated models of biomolecular interaction networks. Genome Research (13), 2498-2504. doi: 10.1101/gr.1239303.metabolite.

Stepanova, A.N., and Alonso, J.M. (2009). Ethylene signaling and response: where different regulatory modules meet. Current opinion in plant biology 12(5),548-555. doi: 10.1016/j.pbi.2009.07.009.

Teige, M., Scheikl, E., Eulgem, T., Doczi, R., Ichimura, K., Shinozaki, K., et al. (2004). The MKK2 Pathway Mediates Cold and Salt Stress Signaling in Arabidopsis. Molecular Cell 15(1), 141-152.

Teklehaimanot, Z. (2004). Physiological Plant Ecology: Ecophysiology and Stress Physiology of Functional Groups, 4th edn. Forestry 77(4), 365-366. doi: 10.1093/forestry/cph039.

Tena, G., Asai, T., Chiu, W.-L., and Sheen, J. (2001). Plant mitogen-activated protein kinase signaling cascades. Current Opinion in Plant Biology 4(5),392-400. doi: https://doi.org/10.1016/S1369-5266(00)00191-6.

The Gene Ontology Consortium, Ashburner, M., Ball, C.A., Blake, J.A., Botstein, D., Butler, H., et al. (2000). Gene Ontology: tool for the unification of biology. Nature genetics 25(1), 25-29. doi: 10.1038/75556. 
The Gene Ontology Consortium (2017). Expansion of the Gene Ontology knowledgebase and resources.Nucleic Acids Research 45(Database issue), D331-D338. doi: 10.1093/nar/gkw1108.

Trapnell, C., Hendrickson, D.G., Sauvageau, M., Goff, L., Rinn, J.L., and Pachter, L. (2013). Differential analysis of gene regulation at transcript resolution with RNA-seq. Nature Biotechnology 31(1). doi: $10.1038 /$ nbt.2450.

Trapnell, C., Pachter, L., and Salzberg, S.L. (2009). TopHat: discovering splice junctions with RNA-Seq. Bioinformatics 25(9), 1105-1111. doi: 10.1093/bioinformatics/btp120.

Trapnell, C., Roberts, A., Goff, L., Pertea, G., Kim, D., Kelley, D.R., et al. (2012). Differential gene and transcript expression analysis of RNA-seq experiments with TopHat and Cufflinks. Nature Protocols 7(3), 562-578. doi: 10.1038/nprot.2012.016.

Trapnell, C., Williams, B.A., Pertea, G., Mortazavi, A., Kwan, G., van Baren, M.J., et al. (2010). Transcript assembly and quantification by RNA-Seq reveals unannotated transcripts and isoform switching during cell differentiation. Nature Biotechnology 28(5), 511-U174. doi: 10.1038/nbt.1621.

Tubiello, F.N., Soussana, J.F., and Howden, S.M. (2007). Crop and pasture response to climate change.Proc Natl Acad Sci U S A 104(50), 19686-19690. doi: 10.1073/pnas.0701728104.

Wang, L., Chen, S., Kong, W., Li, S., and Archbold, D.D. (2006). Salicylic acid pretreatment alleviates chilling injury and affects the antioxidant system and heat shock proteins of peaches during cold storage. Postharvest Biology 85 Technology 41(3), 244-251.

Woodward, A.W., and Bartel, B. (2005). Auxin: Regulation, Action, and Interaction. Ann Bot95(5), 707-735.

Yan, S.C., Chen, J.Y., Yu, W.M., Kuang, J.F., Chen, W.X., Li, X.P., et al. (2011). Expression of genes associated with ethylene-signalling pathway in harvested banana fruit in response to temperature and 1-MCP treatment. Journal of the Science of Food \& Agriculture 91(4), 650-657.

Ye, J., George, C., Irena, Z., Ioana, C., Steve, R., and Madden, T.L. (2012). Primer-BLAST: A tool to design target-specific primers for polymerase chain reaction. Bmc Bioinformatics 13(1), 134.

Yip, A.M., and Horvath, S. (2007). Gene network interconnectedness and the generalized topological overlap measure. BMC Bioinformatics 8, 1-14. doi: 10.1186/1471-2105-8-22.

Yu, Y.-B., Adams, D.O., and Yang, S.F. (1979). 1-Aminocyclopropanecarboxylate synthase, a key enzyme in ethylene biosynthesis. Archives of Biochemistry and Biophysics198(1), 280-286. doi: https://doi.org/10.1016/0003-9861(79)90420-X.

Zhang, L., Yu, Z., Jiang, L., Jiang, J., Luo, H., and Fu, L. (2011). Effect of post-harvest heat treatment on proteome change of peach fruit during ripening. Journal of Proteomics 74(7), 1135-1149. doi: http://dx.doi.org/10.1016/j.jprot.2011.04.012.

Zhang, S., and Klessig, D.F. (2001). MAPK cascades in plant defense signaling. Trends in Plant Science6(11), 520-527. doi: 10.1016/S1360-1385(01)02103-3.

Zhao, Y. (2012). Auxin Biosynthesis: A Simple Two-Step Pathway Converts Tryptophan to Indole-3-Acetic Acid in Plants. Molecular Plant 5(2), 334-338. doi: https://doi.org/10.1093/mp/ssr104. 
(a)

Firmness $\quad$ HT $\square$ CT
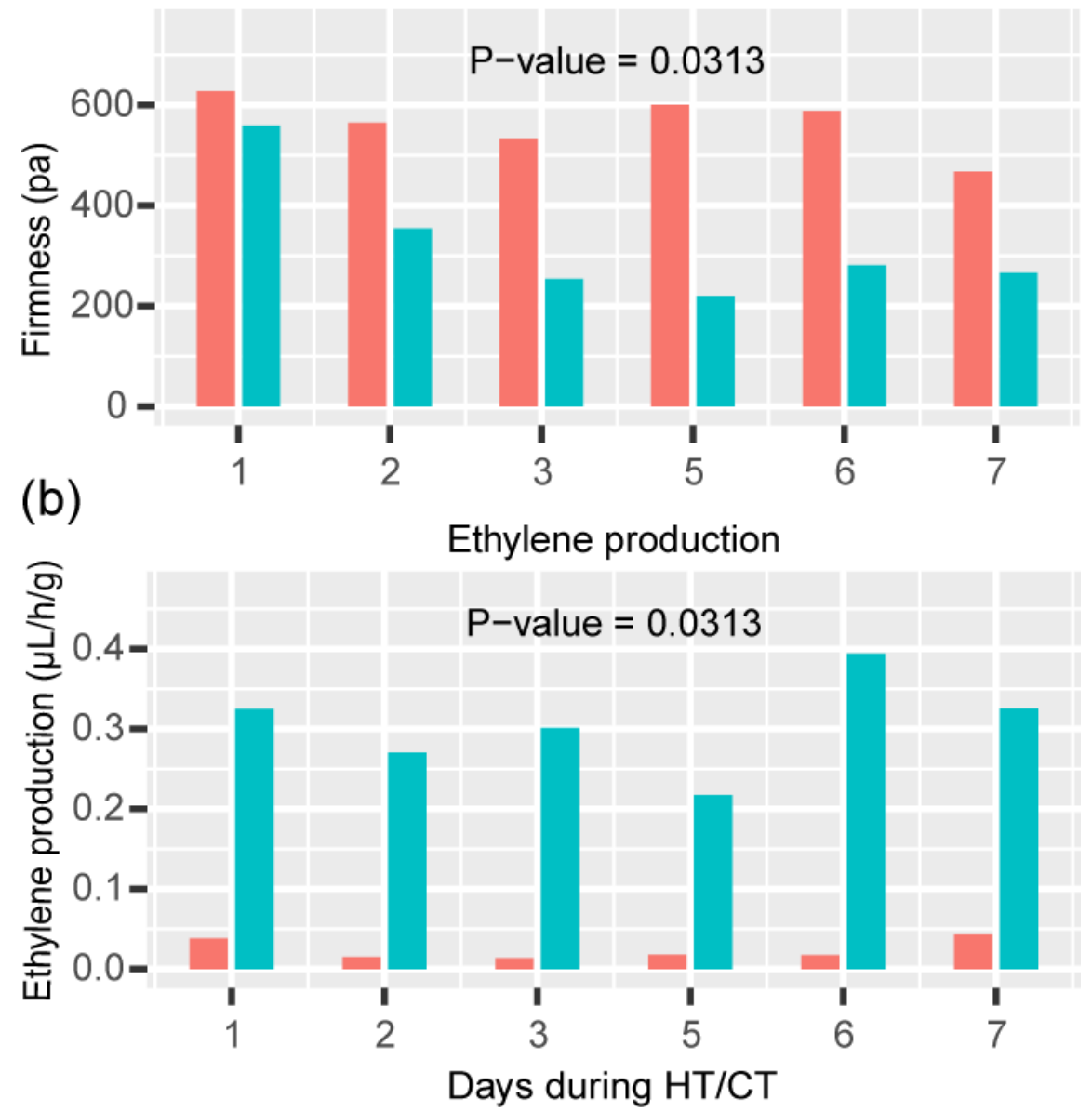
(a)

$=\mathrm{HT} \rightleftharpoons \mathrm{CT}$

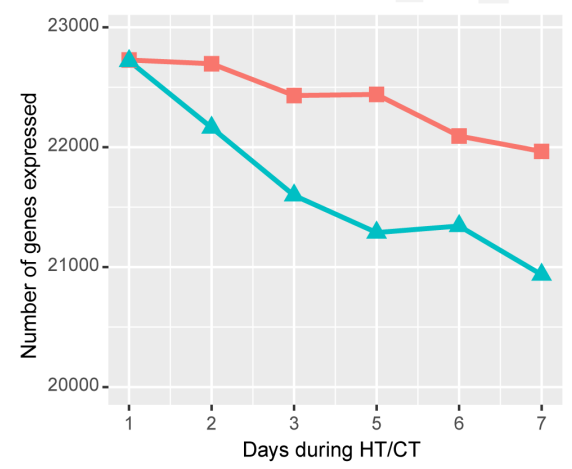

(b)

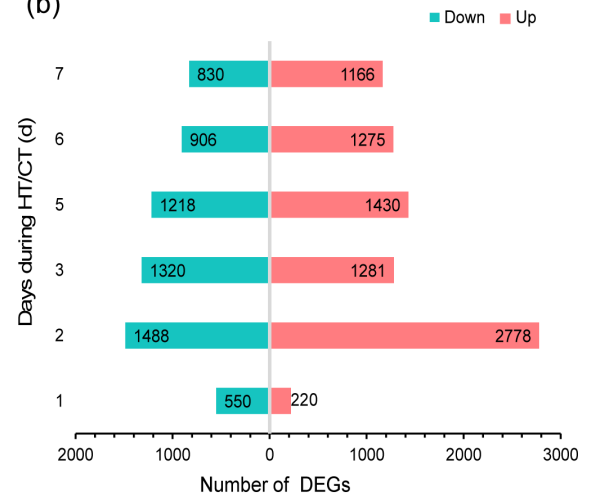

(c)

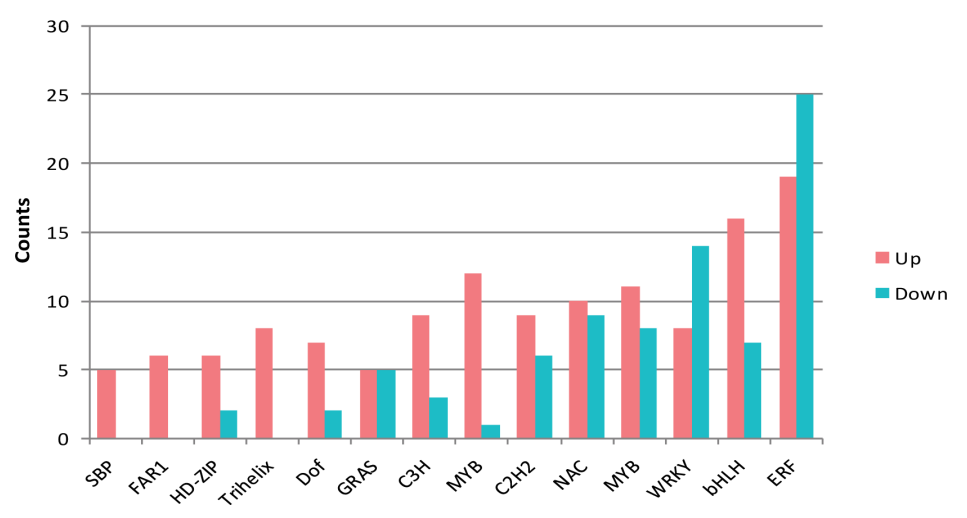


(a)

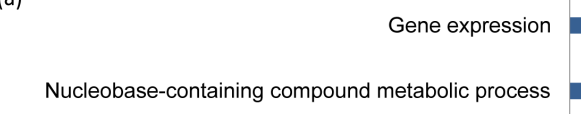

Regulation of nucleobase-containing compound metabolic process

Regulation of transcription, DNA-templated

Regulation of primary metabolic process

Regulation of gene expression

Regulation of cellular macromolecule biosynthetic process

Nucleobase-containing compound biosynthetic process

Nucleic acid metabolic process

Transcription, DNA-templated

0

100

(b)

Translation
Organonitrogen compound biosynthetic process
Organic substance biosynthetic process
Cellular macromolecule biosynthetic process

Cellular nitrogen compound biosynthetic process

Protein ubiquitination

Protein modification by small protein conjugation

Gene expression

Mitochondrial transport

Inorganic ion transmembrane transport

Structural constituent of ribosome

Transcription factor activity, sequence-specific dna binding

Ubiquitin-protein transferase activity

Ribosome

Cytoplasm

Mitochondrial membrane

Mitochondrion

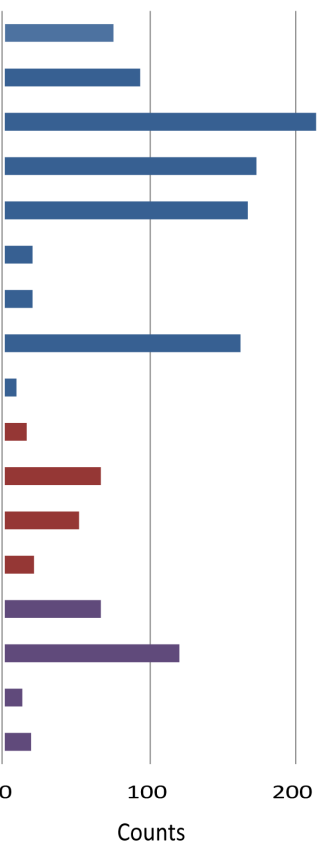

- Biological Process

Molecular Function

Cellular Component 

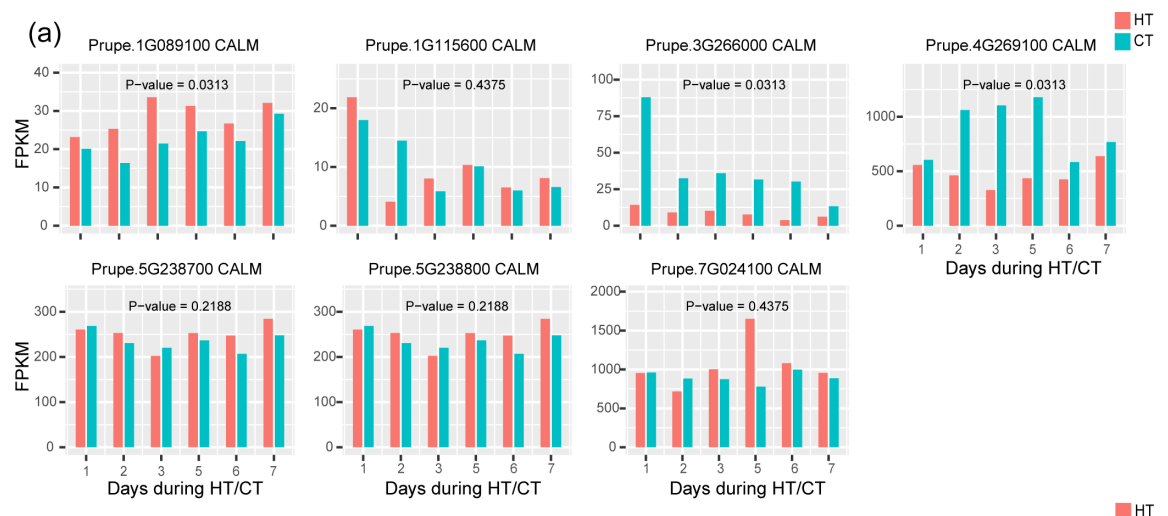

(b) Prupe.1G505800 MEKK1
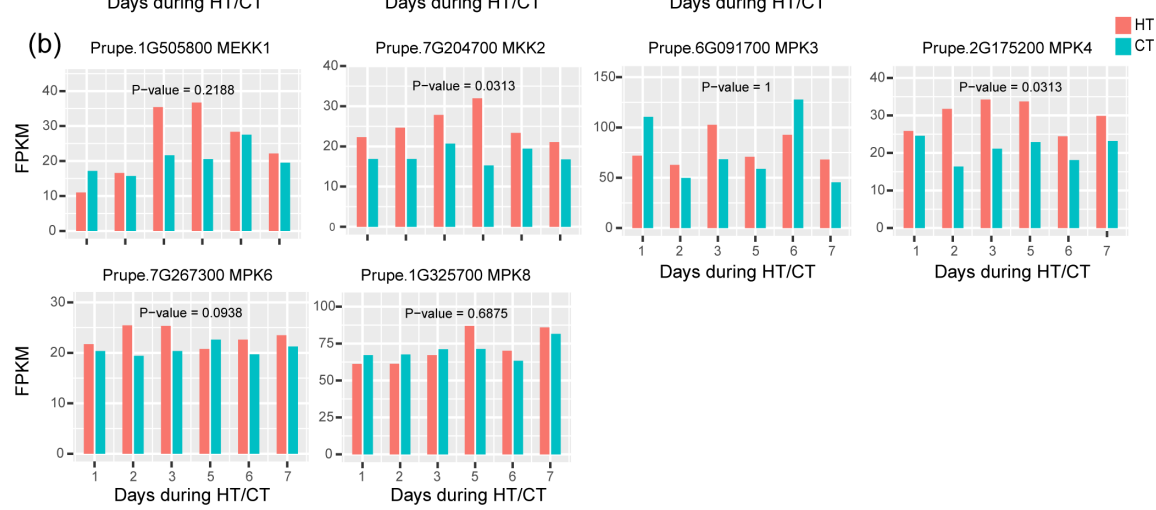

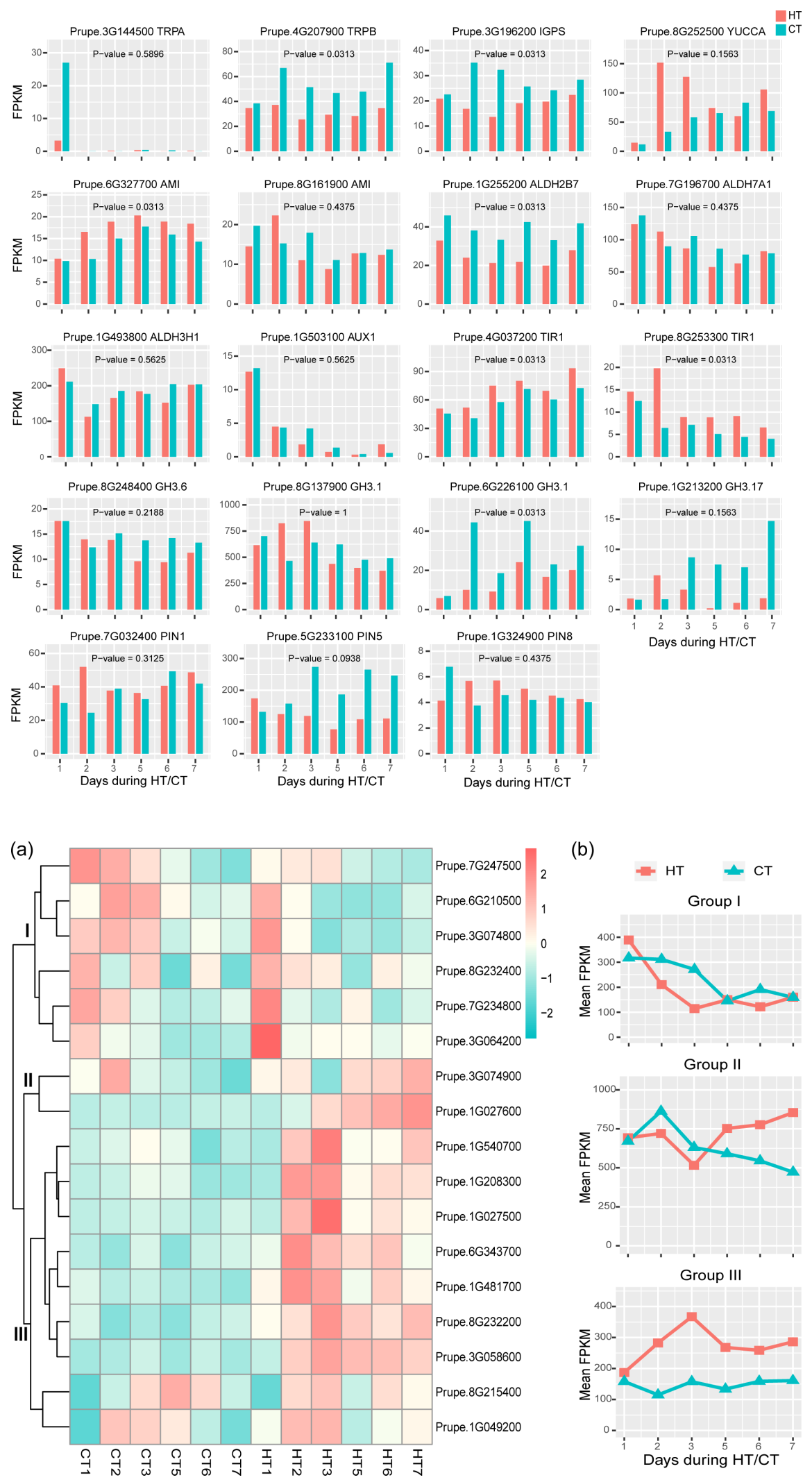

(b)
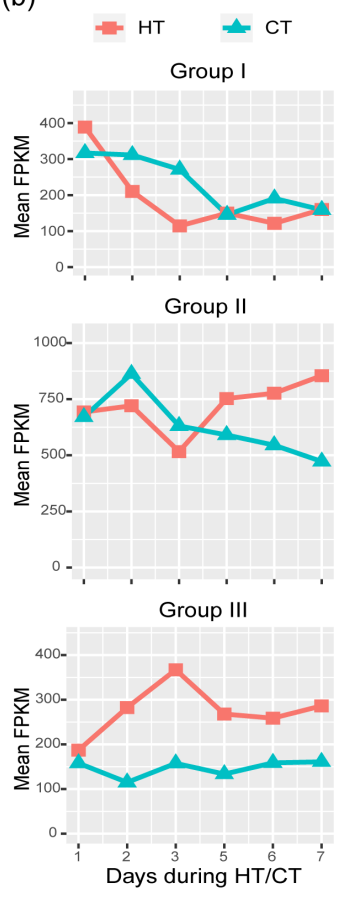


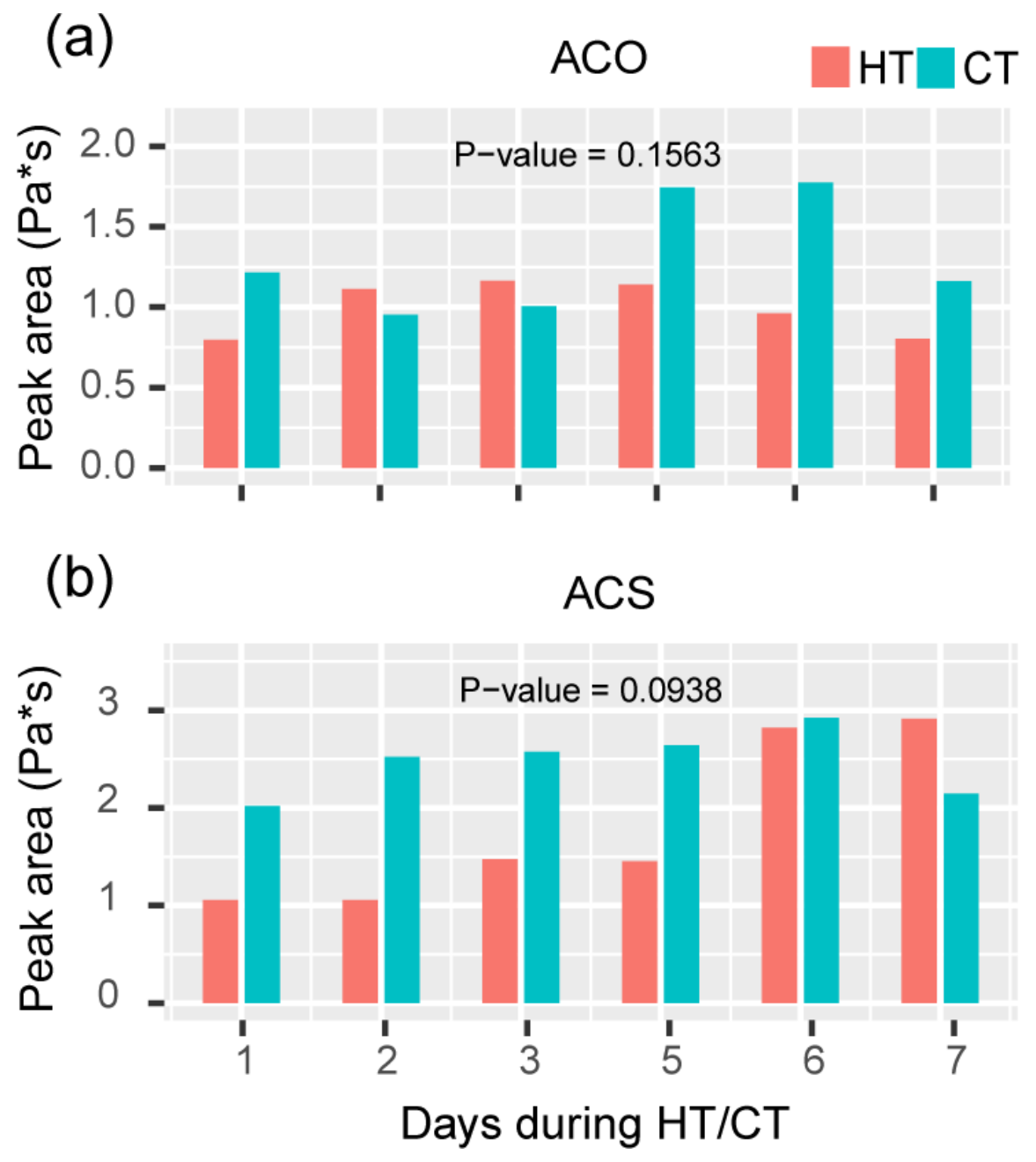


(a) Prupe.16107000 SAMS5
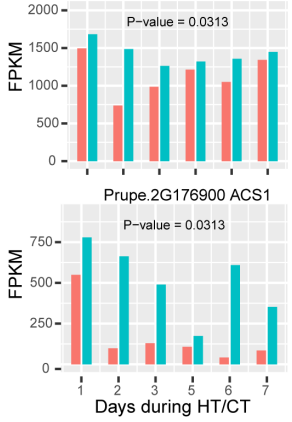

(b)
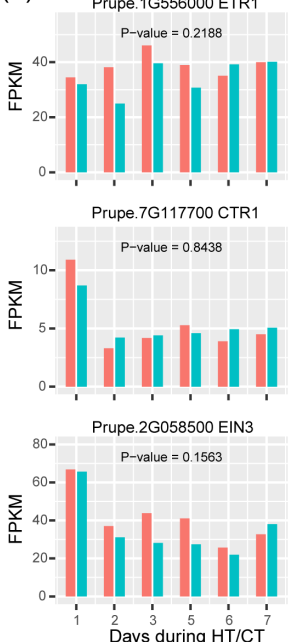
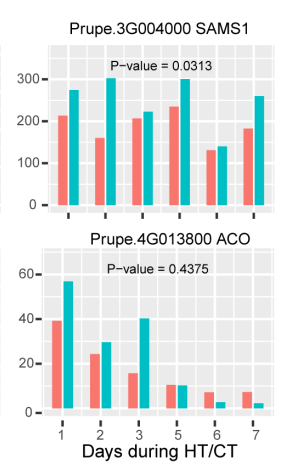

Prupe. 1 G034300 ETR2

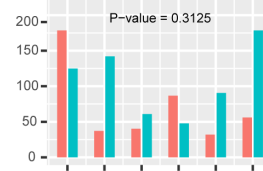

'Plupe

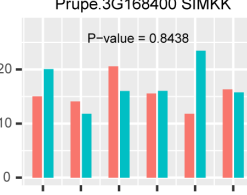

Prupe.2G058400 EIN3

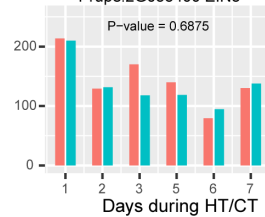

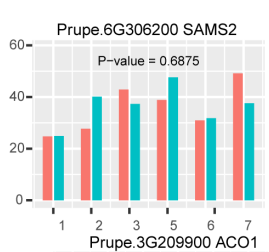
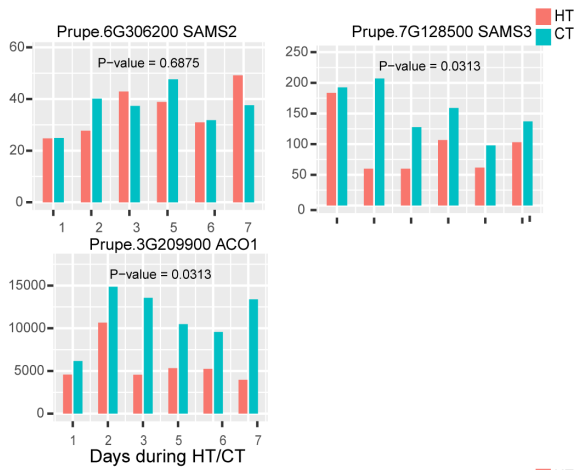

Prupe.8G265200 ERS1
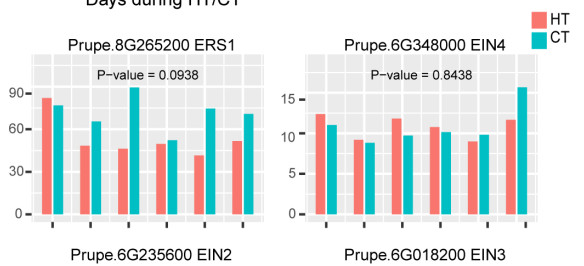

Prupe.6G235600 EIN2

Prupe.6G018200 EIN3
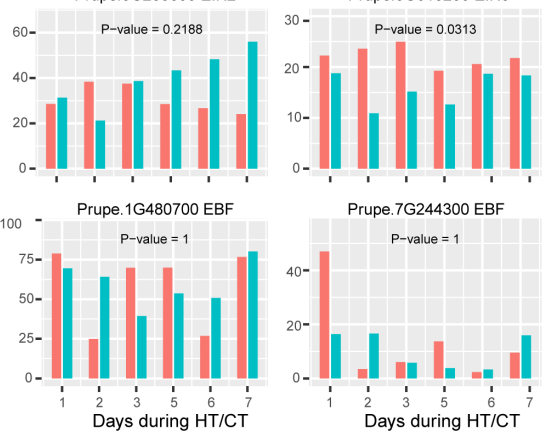

Prupe.7G244300 EBF

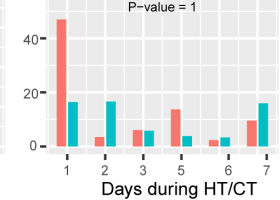


Module-trait relationships

\begin{tabular}{|c|c|c|c|c|c|c|c|c|c|c|c|c|c|c|c|c|c|c|}
\hline MEmediumpurple3 & $\begin{array}{l}-0.013 \\
\text { (1) }\end{array}$ & $\begin{array}{l}-0.24 \\
(0.4)\end{array}$ & $\begin{array}{c}0.013 \\
\text { (1) }\end{array}$ & $\begin{array}{l}-0.45 \\
(0.1)\end{array}$ & $\begin{array}{l}-0.1 \\
(0.8)\end{array}$ & $\begin{array}{c}0.3 \\
(0.3)\end{array}$ & \begin{tabular}{|l|l|}
0.06 \\
$(0.9)$
\end{tabular} & $\begin{array}{l}-0.43 \\
(0.2)\end{array}$ & $\begin{array}{l}-0.3 \\
(0.3)\end{array}$ & $\begin{array}{l}0.078 \\
(0.8)\end{array}$ & $\begin{array}{l}0.37 \\
(0.2)\end{array}$ & $\begin{array}{l}-0.42 \\
(0.2)\end{array}$ & $\begin{array}{l}0.22 \\
(0.5)\end{array}$ & $\begin{array}{l}-0.35 \\
(0.3)\end{array}$ & $\begin{array}{l}0.1 \\
(0.8)\end{array}$ & $\begin{array}{l}0.41 \\
(0.2)\end{array}$ & $\begin{array}{c}0.55 \\
(0.06)\end{array}$ & \begin{tabular}{l|}
0.01 \\
(1)
\end{tabular} \\
\hline MEmidnightblue & $\begin{array}{c}-0.088 \\
(0.8)\end{array}$ & $\begin{array}{l}-0.19 \\
(0.6)\end{array}$ & $\begin{array}{c}0.0058 \\
(1)\end{array}$ & $\begin{array}{l}-0.7 \\
(0.01)\end{array}$ & $\begin{array}{l}0.23 \\
(0.5)\end{array}$ & $\begin{array}{l}0.47 \\
(0.1)\end{array}$ & $\begin{array}{l}-0.19 \\
(0.5)\end{array}$ & $\begin{array}{l}-0.062 \\
(0.8)\end{array}$ & $\begin{array}{l}-0.33 \\
(0.3)\end{array}$ & $\begin{array}{l}0.17 \\
(0.6)\end{array}$ & $\begin{array}{c}0.56 \\
(0.06)\end{array}$ & $\begin{array}{l}-0.25 \\
(0.4)\end{array}$ & $\begin{array}{c}-0.0073- \\
\text { (1) }\end{array}$ & $\begin{array}{l}3-0.078 \\
(0.8)\end{array}$ & $\begin{array}{l}-0.17 \\
(0.6)\end{array}$ & $\begin{array}{l}0.13 \\
(0.7)\end{array}$ & $\begin{array}{l}0.37 \\
(0.2)\end{array}$ & $\begin{array}{c}0.016 \\
(1)\end{array}$ \\
\hline MElightcyan1 & $\begin{array}{l}-0.0078 \\
(1)\end{array}$ & $\begin{array}{l}3.6 \\
(0.04)\end{array}$ & $\begin{array}{c}0.52 \\
(0.08)\end{array}$ & $\begin{array}{c}-0.0076 \\
\text { (1) }\end{array}$ & $\begin{array}{l}6-0.074 \\
(0.8)\end{array}$ & 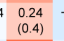 & $\begin{array}{l}-0.17 \\
(0.6)\end{array}$ & $\begin{array}{l}-0.39 \\
(0.2)\end{array}$ & $\begin{array}{l}0.056 \\
(0.9)\end{array}$ & $\begin{array}{c}-0.6 \\
(0.04)\end{array}$ & $\begin{array}{l}0.074 \\
(0.8)\end{array}$ & $\begin{array}{l}0.07 \\
(0.8)\end{array}$ & $\begin{array}{l}0.36 \\
(0.3)\end{array}$ & $\begin{array}{l}-0.23 \\
(0.5)\end{array}$ & $\begin{array}{c}-0.39 \\
(0.2)\end{array}$ & $\begin{array}{l}-0.38 \\
(0.2)\end{array}$ & $\begin{array}{l}0.39 \\
(0.2)\end{array}$ & $\begin{array}{l}0.11 \\
(0.7)\end{array}$ \\
\hline MEfloralwhite & $\begin{array}{l}-0.57 \\
(0.05)\end{array}$ & $\begin{array}{l}0.13 \\
(0.7)\end{array}$ & $\begin{array}{l}0.043 \\
(0.9)\end{array}$ & $\begin{array}{l}-0.61 \\
(0.04)\end{array}$ & $\begin{array}{l}-0.15 \\
(0.6)\end{array}$ & $\begin{array}{c}0.7 \\
(0.01)\end{array}$ & $\begin{array}{c}-0.14 \\
(0.7)\end{array}$ & $\begin{array}{l}0.13 \\
(0.7)\end{array}$ & $\begin{array}{l}-0.63 \\
(0.03)\end{array}$ & $\begin{array}{l}-0.14 \\
(0.7)\end{array}$ & $\begin{array}{c}0.58 \\
(0.05)\end{array}$ & $\begin{array}{l}-0.31 \\
(0.3)\end{array}$ & $\begin{array}{l}-0.29 \\
(0.4)\end{array}$ & $\begin{array}{l}0.26 \\
(0.4)\end{array}$ & $\begin{array}{c}-0.6 \\
(0.04)\end{array}$ & $\begin{array}{l}-0.07 \\
(0.8)\end{array}$ & $\begin{array}{l}0.074 \\
(0.8)\end{array}$ & $\begin{array}{c}-0.019 \\
(1)\end{array}$ \\
\hline MEdarkolivegreen & $\begin{array}{l}-0.67 \\
(0.02)\end{array}$ & $\begin{array}{l}0.24 \\
(0.4)\end{array}$ & $\begin{array}{l}0.037 \\
(0.9)\end{array}$ & $\begin{array}{l}-0.53 \\
(0.08)\end{array}$ & $\begin{array}{l}-0.48 \\
(0.1)\end{array}$ & $\begin{array}{c}0.57 \\
(0.05)\end{array}$ & $\begin{array}{c}-0.14 \\
(0.7)\end{array}$ & $\begin{array}{c}-0.085 \\
(0.8)\end{array}$ & $\begin{array}{l}-0.46 \\
(0.1)\end{array}$ & $\begin{array}{l}-0.45 \\
(0.1)\end{array}$ & $\begin{array}{c}0.56 \\
(0.06)\end{array}$ & $\begin{array}{l}-0.28 \\
(0.4)\end{array}$ & $\begin{array}{l}-0.23 \\
(0.5)\end{array}$ & $\begin{array}{l}0.049 \\
(0.9)\end{array}$ & $\begin{array}{l}-0.43 \\
(0.2)\end{array}$ & $\begin{array}{l}-0.2 \\
(0.5)\end{array}$ & $\begin{array}{l}0.0021 \\
\text { (1) }\end{array}$ & $\begin{array}{l}0.42 \\
(0.2)\end{array}$ \\
\hline MEskyblue & $\begin{array}{c}-0.34 \\
(0.3)\end{array}$ & $\begin{array}{l}0.34 \\
(0.3)\end{array}$ & $\begin{array}{l}0.29 \\
(0.4)\end{array}$ & $\begin{array}{c}-0.49 \\
(0.1)\end{array}$ & $\begin{array}{c}-0.12 \\
(0.7)\end{array}$ & $\begin{array}{l}0.49 \\
(0.1)\end{array}$ & $\begin{array}{c}-0.41 \\
(0.2)\end{array}$ & $\begin{array}{l}-0.29 \\
(0.4)\end{array}$ & $\begin{array}{l}-0.14 \\
(0.7)\end{array}$ & $\begin{array}{l}-0.47 \\
(0.1)\end{array}$ & $\begin{array}{c}0.56 \\
(0.06)\end{array}$ & $\begin{array}{l}0.041 \\
(0.9)\end{array}$ & $\begin{array}{l}0.075 \\
(0.8)\end{array}$ & $\begin{array}{l}-0.18 \\
(0.6)\end{array}$ & $\begin{array}{l}-0.43 \\
(0.2)\end{array}$ & $\begin{array}{l}-0.41 \\
(0.2)\end{array}$ & $\begin{array}{l}0.33 \\
(0.3)\end{array}$ & $\begin{array}{l}0.43 \\
(0.2)\end{array}$ \\
\hline MEsaddlebrown & $\begin{array}{c}-0.29 \\
(0.4)\end{array}$ & $\begin{array}{l}-0.47 \\
(0.1)\end{array}$ & $\begin{array}{c}0.1 \\
(0.8)\end{array}$ & $\begin{array}{l}-0.16 \\
(0.6)\end{array}$ & $\begin{array}{c}-0.035 \\
(0.9)\end{array}$ & $5 \begin{array}{c}0.53 \\
(0.08)\end{array}$ & $\begin{array}{l}0.082 \\
(0.8)\end{array}$ & $\begin{array}{l}0.13 \\
(0.7)\end{array}$ & $\begin{array}{l}-0.76 \\
(0.004)\end{array}$ & $\begin{array}{l}0.38 \\
(0.2)\end{array}$ & $\begin{array}{l}0.27 \\
(0.4)\end{array}$ & $\begin{array}{l}-0.88 \\
(2 e-04)\end{array}$ & $\begin{array}{l}-0.32 \\
(0.3)\end{array}$ & $\begin{array}{l}0.038 \\
(0.9)\end{array}$ & $\begin{array}{l}0.12 \\
(0.7)\end{array}$ & $\begin{array}{c}0.68 \\
(0.01)\end{array}$ & $\begin{array}{c}-0.13 \\
(0.7)\end{array}$ & $\begin{array}{c}-0.47 \\
(0.1)\end{array}$ \\
\hline MEcyan & $\begin{array}{l}-0.42 \\
(0.2)\end{array}$ & $\begin{array}{l}-0.36 \\
(0.3)\end{array}$ & $\begin{array}{l}-0.068 \\
(0.8)\end{array}$ & $\begin{array}{c}-0.27 \\
(0.4)\end{array}$ & $\begin{array}{l}-0.5 \\
(0.1)\end{array}$ & $\begin{array}{l}0.48 \\
(0.1)\end{array}$ & $\begin{array}{l}0.19 \\
(0.6)\end{array}$ & $\begin{array}{l}-0.21 \\
(0.5)\end{array}$ & $\begin{array}{l}-0.69 \\
(0.01)\end{array}$ & $\begin{array}{l}0.082 \\
(0.8)\end{array}$ & $\begin{array}{l}0.38 \\
(0.2)\end{array}$ & $\begin{array}{c}-0.81 \\
(0.001)\end{array}$ & $\begin{array}{l}-0.096 \\
(0.8)\end{array}$ & $\begin{array}{l}-0.13 \\
(0.7)\end{array}$ & $\begin{array}{l}0.15 \\
(0.6)\end{array}$ & $\begin{array}{c}0.67 \\
(0.02)\end{array}$ & $\begin{array}{l}0.077 \\
(0.8)\end{array}$ & $\begin{array}{l}-0.13 \\
(0.7)\end{array}$ \\
\hline MEgrey60 & $\begin{array}{c}0.014 \\
\text { (1) }\end{array}$ & $\begin{array}{l}-0.5 \\
(0.1)\end{array}$ & $\begin{array}{l}-0.59 \\
(0.05)\end{array}$ & $\begin{array}{l}-0.21 \\
(0.5)\end{array}$ & $\begin{array}{l}-0.32 \\
(0.3)\end{array}$ & -0.02 & $\begin{array}{r}0.57 \\
(0.05)\end{array}$ & $\begin{array}{l}0.021 \\
(0.9)\end{array}$ & $\begin{array}{l}-0.35 \\
(0.3)\end{array}$ & $\begin{array}{l}0.44 \\
(0.1)\end{array}$ & $\begin{array}{l}0.04 \\
(0.9)\end{array}$ & $\begin{array}{l}-0.52 \\
(0.08)\end{array}$ & $\begin{array}{l}0.068 \\
(0.8)\end{array}$ & $\begin{array}{l}0.079 \\
(0.8)\end{array}$ & $\begin{array}{c}0.4 \\
(0.2)\end{array}$ & $\begin{array}{c}0.85 \\
(5 e-04)\end{array}$ & $\begin{array}{l}0.033 \\
(0.9)\end{array}$ & $\begin{array}{l}-0.3 \\
(0.4)\end{array}$ \\
\hline MEgreen & \begin{tabular}{|c|}
-0.48 \\
$(0.1)$
\end{tabular} & $\begin{array}{l}-0.34 \\
(0.3)\end{array}$ & $\begin{array}{l}-0.13 \\
(0.7)\end{array}$ & $\begin{array}{c}-0.32 \\
(0.3)\end{array}$ & $\begin{array}{l}0.14 \\
(0.7)\end{array}$ & $\begin{array}{c}0.39 \\
(0.2)\end{array}$ & $\begin{array}{r}-0.076 \\
(0.8)\end{array}$ & $\begin{array}{c}0.83 \\
(90-04)\end{array}$ & $\begin{array}{l}-0.52 \\
(0.08)\end{array}$ & $\begin{array}{l}0.32 \\
(0.3)\end{array}$ & $\begin{array}{l}0.28 \\
(0.4)\end{array}$ & $\begin{array}{c}-0.33 \\
(0.3)\end{array}$ & $\begin{array}{c}-0.73 \\
(0.007)\end{array}$ & $\begin{array}{c}0.66 \\
(0.02) \\
(0.02)\end{array}$ & $\begin{array}{l}-0.2 \\
(0.5)\end{array}$ & $\begin{array}{l}0.021 \\
(0.9)\end{array}$ & $\begin{array}{l}-0.78 \\
(0.003)\end{array}$ & $\begin{array}{l}-0.24 \\
(0.4)\end{array}$ \\
\hline MEdarkorange2 & \begin{tabular}{|c|}
0.059 \\
$(0.9)$
\end{tabular} & $\begin{array}{l}-0.6 \\
(0.04)\end{array}$ & $\begin{array}{c}-0.6 \\
(0.04)\end{array}$ & $\begin{array}{l}-0.65 \\
(0.02)\end{array}$ & $\begin{array}{l}0.33 \\
(0.3)\end{array}$ & $\begin{array}{l}0.01 \\
\text { (1) }\end{array}$ & $\begin{array}{l}0.31 \\
(0.3)\end{array}$ & $\begin{array}{c}0.59 \\
(0.04)\end{array}$ & $\begin{array}{l}-0.33 \\
(0.3)\end{array}$ & $\begin{array}{c}0.76 \\
(0.004)\end{array}$ & $\begin{array}{l}0.078 \\
(0.8)\end{array}$ & $\begin{array}{l}-0.37 \\
(0.2)\end{array}$ & $\begin{array}{l}-0.36 \\
(0.3)\end{array}$ & $\begin{array}{l}0.35 \\
(0.3)\end{array}$ & $\begin{array}{l}0.11 \\
(0.7)\end{array}$ & $\begin{array}{c}0.51 \\
(0.09)\end{array}$ & $\begin{array}{l}-0.21 \\
(0.5)\end{array}$ & $\begin{array}{c}-0.36 \\
(0.2)\end{array}$ \\
\hline MElightgreen & \begin{tabular}{|c|}
-0.5 \\
$(0.09)$
\end{tabular} & $\begin{array}{c}-0.4 \\
(0.2)\end{array}$ & $\begin{array}{l}-0.38 \\
(0.2)\end{array}$ & $\begin{array}{l}-0.52 \\
(0.08)\end{array}$ & $\begin{array}{l}-0.24 \\
(0.5)\end{array}$ & $\begin{array}{l}0.47 \\
(0.1)\end{array}$ & $\begin{array}{l}0.34 \\
(0.3)\end{array}$ & $\begin{array}{l}0.45 \\
(0.1)\end{array}$ & $\begin{array}{c}-0.79 \\
(0.002)\end{array}$ & $\begin{array}{l}0.35 \\
(0.3)\end{array}$ & $\begin{array}{l}0.33 \\
(0.3)\end{array}$ & $\begin{array}{c}-0.76 \\
(0.004)\end{array}$ & $\begin{array}{l}-0.52 \\
(0.08)\end{array}$ & $\begin{array}{l}0.42 \\
(0.2)\end{array}$ & $\begin{array}{c}-0.091 \\
(0.8)\end{array}$ & $\begin{array}{c}0.55 \\
(0.06)\end{array}$ & $\begin{array}{l}-0.35 \\
(0.3)\end{array}$ & $\begin{array}{c}-0.28 \\
(0.4)\end{array}$ \\
\hline MEbisque4 & \begin{tabular}{|c}
-0.46 \\
$(0.1)$
\end{tabular} & $\begin{array}{c}-0.33 \\
(0.3)\end{array}$ & -0.0085 & $\begin{array}{r}5-0.67 \\
(0.02)\end{array}$ & $\begin{array}{l}-0.06 \\
(0.9)\end{array}$ & $\begin{array}{c}0.77 \\
(0.009)\end{array}$ & $\begin{array}{c}0.014 \\
\text { (1) }\end{array}$ & $\begin{array}{l}0.07 \\
(0.8)\end{array}$ & $\begin{array}{c}-0.83 \\
(9 e-04)\end{array}$ & $\begin{array}{l}0.23 \\
(0.5)\end{array}$ & $\begin{array}{c}0.58 \\
(0.05)\end{array}$ & $\begin{array}{l}-0.76 \\
(0.004)\end{array}$ & $\begin{array}{l}-0.35 \\
(0.3)\end{array}$ & $\begin{array}{l}0.065 \\
(0.8)\end{array}$ & $\begin{array}{c}-0.22 \\
(0.5)\end{array}$ & $\begin{array}{l}0.45 \\
(0.1)\end{array}$ & $\begin{array}{l}0.13 \\
(0.7)\end{array}$ & $\begin{array}{c}-0.19 \\
(0.6)\end{array}$ \\
\hline MElightsteelblue1 & $\begin{array}{l}-0.71 \\
(0.01)\end{array}$ & $\begin{array}{l}-0.19 \\
(0.5)\end{array}$ & $\begin{array}{l}0.14 \\
(0.7)\end{array}$ & $\begin{array}{l}-0.66 \\
(0.02)\end{array}$ & $\begin{array}{c}-0.029 \\
(0.9)\end{array}$ & $\begin{array}{c}9.86 \\
(4 e-04)\end{array}$ & $\begin{array}{l}-0.3 \\
(0.4)\end{array}$ & $\begin{array}{l}0.35 \\
(0.3)\end{array}$ & $\begin{array}{c}-0.87 \\
(2 \mathrm{e}-04)\end{array}$ & $\begin{array}{l}0.092 \\
(0.8)\end{array}$ & $\begin{array}{c}0.67 \\
(0.02)\end{array}$ & $\begin{array}{c}-0.71 \\
(0.009)\end{array}$ & $\begin{array}{c}-0.6 \\
(0.04)\end{array}$ & $\begin{array}{l}0.21 \\
(0.5)\end{array}$ & $\begin{array}{c}-0.37 \\
(0.2)\end{array}$ & $\begin{array}{l}0.14 \\
(0.7)\end{array}$ & $\begin{array}{c}-0.27 \\
(0.4)\end{array}$ & $\begin{array}{c}-0.071 \\
(0.8)\end{array}$ \\
\hline MEskyblue3 & $\begin{array}{c}0.53 \\
(0.08)\end{array}$ & $\begin{array}{l}0.14 \\
(0.7)\end{array}$ & $\begin{array}{l}0.023 \\
(0.9)\end{array}$ & $\begin{array}{l}0.44 \\
(0.2)\end{array}$ & $\begin{array}{l}0.096 \\
(0.8)\end{array}$ & $\begin{array}{c}-0.7 \\
(0.01)\end{array}$ & $\begin{array}{l}-0.1 \\
(0.7)\end{array}$ & $\begin{array}{l}-0.36 \\
(0.2)\end{array}$ & $\begin{array}{c}0.93 \\
(1 \mathrm{e}-05)\end{array}$ & $\begin{array}{l}-0.23 \\
(0.5)\end{array}$ & $\begin{array}{c}-0.32 \\
(0.3)\end{array}$ & $\begin{array}{c}0.86 \\
(3 e-04)\end{array}$ & $\begin{array}{l}0.48 \\
(0.1)\end{array}$ & $\begin{array}{l}-0.29 \\
(0.4)\end{array}$ & $\begin{array}{l}0.35 \\
(0.3)\end{array}$ & $\begin{array}{l}-0.47 \\
(0.1)\end{array}$ & $\begin{array}{l}0.19 \\
(0.6)\end{array}$ & $\begin{array}{l}0.46 \\
(0.1)\end{array}$ \\
\hline MEplum1 & $\left(\begin{array}{c}0.54 \\
0.07) \\
(0.07)\end{array}\right.$ & $\begin{array}{c}0.0088 \\
(1)\end{array}$ & $\begin{array}{c}-0.073 \\
(0.8)\end{array}$ & $\begin{array}{c}-0.053 \\
(0.9)\end{array}$ & $\begin{array}{l}0.49 \\
(0.1)\end{array}$ & $\begin{array}{l}-0.43 \\
(0.2)\end{array}$ & $\begin{array}{c}-0.22 \\
(0.5)\end{array}$ & $\begin{array}{l}-0.06 \\
(0.9)\end{array}$ & $\begin{array}{c}0.69 \\
(0.01)\end{array}$ & $\begin{array}{l}0.086 \\
(0.8)\end{array}$ & $\begin{array}{c}-0.067 \\
(0.8)\end{array}$ & $\begin{array}{c}0.73 \\
(0.007)\end{array}$ & $\begin{array}{l}0.34 \\
(0.3)\end{array}$ & $\begin{array}{l}-0.1 \\
(0.7)\end{array}$ & $\begin{array}{l}0.13 \\
(0.7)\end{array}$ & $\begin{array}{l}-0.39 \\
(0.2)\end{array}$ & $\begin{array}{l}0.25 \\
(0.4)\end{array}$ & $\begin{array}{l}0.23 \\
(0.5)\end{array}$ \\
\hline MEwhite & $\begin{array}{l}0.14 \\
0.74 \\
(0.7)\end{array}$ & $\begin{array}{l}0.34 \\
(0.3)\end{array}$ & $\begin{array}{l}0.19 \\
(0.6)\end{array}$ & $\begin{array}{l}-0.15 \\
(0.6)\end{array}$ & $\begin{array}{l}0.092 \\
(0.8)\end{array}$ & $\begin{array}{l}-0.086 \\
(0.8)\end{array}$ & $\begin{array}{l}-0.38 \\
(0.2)\end{array}$ & $\begin{array}{l}-0.35 \\
(0.3)\end{array}$ & $\begin{array}{c}0.5 \\
(0.1)\end{array}$ & $\begin{array}{l}-0.43 \\
(0.2)\end{array}$ & $\begin{array}{l}0.21 \\
(0.5)\end{array}$ & $\begin{array}{c}0.6 \\
(0.04)\end{array}$ & $\begin{array}{l}0.34 \\
(0.3)\end{array}$ & $\begin{array}{l}-0.26 \\
(0.4)\end{array}$ & $\begin{array}{l}-0.13 \\
(0.7)\end{array}$ & $\begin{array}{l}-0.62 \\
(0.03)\end{array}$ & $\begin{array}{l}0.35 \\
(0.3)\end{array}$ & $\left.\begin{array}{c}0.57 \\
(0.05)\end{array}\right]$ \\
\hline MElightyellow & $\begin{array}{c}-0.19 \\
(0.6)\end{array}$ & $\begin{array}{c}0.59 \\
(0.04)\end{array}$ & $\begin{array}{l}0.47 \\
(0.1)\end{array}$ & $\begin{array}{l}0.47 \\
(0.1)\end{array}$ & $\begin{array}{c}-0.6 \\
(0.04)\end{array}$ & $\begin{array}{l}-0.078 \\
(0.8)\end{array}$ & $\begin{array}{c}-0.23 \\
(0.5)\end{array}$ & $\begin{array}{c}-0.7 \\
(0.01)\end{array}$ & $\begin{array}{l}0.34 \\
(0.3)\end{array}$ & $\begin{array}{r}-0.89 \\
(9 \mathrm{e}-05\end{array}$ & $\begin{array}{c}-0.054 \\
(0.9)\end{array}$ & $\begin{array}{l}4 \begin{array}{l}0.31 \\
(0.3)\end{array} \\
\end{array}$ & $\begin{array}{l}0.35 \\
(0.3)\end{array}$ & $\begin{array}{l}-0.46 \\
(0.1)\end{array}$ & $\begin{array}{c}-0.059 \\
(0.9)\end{array}$ & $\begin{array}{c}-0.52 \\
(0.08)\end{array}$ & $\begin{array}{l}0.22 \\
(0.5)\end{array}$ & $\begin{array}{c}0.61 \\
(0.04)\end{array}$ \\
\hline MEred & $\begin{array}{l}0.057 \\
(0.9)\end{array}$ & $\begin{array}{l}0.44 \\
(0.2)\end{array}$ & $\begin{array}{l}0.35 \\
(0.3)\end{array}$ & $\begin{array}{c}0.79 \\
(0.002)\end{array}$ & $\begin{array}{l}-0.36 \\
(0.3)\end{array}$ & $\begin{array}{c}-0.34 \\
(0.3)\end{array}$ & $\begin{array}{c}-0.05 \\
(0.9)\end{array}$ & $\begin{array}{l}-0.41 \\
(0.2)\end{array}$ & $\begin{array}{l}0.43 \\
(0.2)\end{array}$ & $\begin{array}{l}-0.56 \\
(0.06)\end{array}$ & $\begin{array}{l}-0.41 \\
(0.2)\end{array}$ & $\begin{array}{l}0.37 \\
(0.2)\end{array}$ & $\begin{array}{l}0.26 \\
(0.4)\end{array}$ & $\begin{array}{l}-0.26 \\
(0.4)\end{array}$ & $\begin{array}{l}0.082 \\
(0.8)\end{array}$ & $\begin{array}{l}-0.36 \\
(0.2)\end{array}$ & $\begin{array}{r}-0.0054 \\
\text { (1) }\end{array}$ & $\left.\begin{array}{c}4 \\
0.24 \\
(0.4)\end{array}\right]$ \\
\hline MEbrown4 & $\begin{array}{c}-0.38 \\
(0.2)\end{array}$ & $\begin{array}{l}0.45 \\
(0.1)\end{array}$ & $\begin{array}{c}0.3 \\
(0.3)\end{array}$ & $\begin{array}{l}0.049 \\
(0.9)\end{array}$ & $\begin{array}{l}-0.49 \\
(0.1)\end{array}$ & $\begin{array}{l}0.08 \\
(0.8)\end{array}$ & $\begin{array}{l}-0.44 \\
(0.1)\end{array}$ & $\begin{array}{r}-0.53 \\
(0.08)\end{array}$ & $\begin{array}{l}0.25 \\
(0.4)\end{array}$ & $\begin{array}{c}-0.77 \\
(0.003)\end{array}$ & $\begin{array}{l}0.27 \\
(0.4)\end{array}$ & $\begin{array}{l}0.31 \\
(0.3)\end{array}$ & $\begin{array}{l}0.091 \\
(0.8)\end{array}$ & $\begin{array}{l}-0.42 \\
(0.2)\end{array}$ & $\begin{array}{c}-0.12 \\
(0.7)\end{array}$ & $\begin{array}{c}-0.62 \\
(0.03)\end{array}$ & $\begin{array}{l}0.11 \\
(0.7)\end{array}$ & $\begin{array}{c}0.9 \\
\left(8 e^{-05}\right)\end{array}$ \\
\hline MEdarkgrey & $\begin{array}{c}-0.3 \\
(0.3)\end{array}$ & $\begin{array}{c}0.57 \\
(0.05)\end{array}$ & $\begin{array}{c}0.53 \\
(0.08)\end{array}$ & $\begin{array}{l}0.046 \\
(0.9)\end{array}$ & $\begin{array}{l}-0.44 \\
(0.2)\end{array}$ & $\begin{array}{l}0.28 \\
(0.4)\end{array}$ & $\begin{array}{l}-0.45 \\
(0.1)\end{array}$ & $\begin{array}{l}-0.68 \\
(0.01)\end{array}$ & $\begin{array}{l}0.16 \\
(0.6)\end{array}$ & $\begin{array}{c}-0.87 \\
(2 \mathrm{e}-04)\end{array}$ & $\begin{array}{l}0.37 \\
(0.2)\end{array}$ & $\begin{array}{l}0.22 \\
(0.5)\end{array}$ & $\begin{array}{l}0.32 \\
(0.3)\end{array}$ & $\begin{array}{l}-0.46 \\
(0.1)\end{array}$ & $\begin{array}{c}-0.22 \\
(0.5)\end{array}$ & $\begin{array}{l}-0.57 \\
(0.06)\end{array}$ & $\begin{array}{l}0.35 \\
(0.3)\end{array}$ & $\begin{array}{l}0.71 \\
(0.01)\end{array}$ \\
\hline MEbrown & \begin{tabular}{|l|}
0.39 \\
$(0.2)$
\end{tabular} & $\begin{array}{l}0.084 \\
(0.8)\end{array}$ & $\begin{array}{l}0.091 \\
(0.8)\end{array}$ & $\begin{array}{c}0.81 \\
(0.001)\end{array}$ & $\begin{array}{l}0.16 \\
(0.6)\end{array}$ & $\begin{array}{c}-0.44 \\
(0.1)\end{array}$ & $\begin{array}{l}0.11 \\
(0.7)\end{array}$ & $\begin{array}{c}-0.016 \\
\text { (1) }\end{array}$ & $\begin{array}{l}0.42 \\
(0.2)\end{array}$ & $\begin{array}{l}0.066 \\
(0.8)\end{array}$ & $\begin{array}{c}-0.5 \\
(0.09)\end{array}$ & $\begin{array}{l}0.35 \\
(0.3)\end{array}$ & $\begin{array}{l}0.15 \\
(0.6)\end{array}$ & $\begin{array}{l}0.02 \\
\text { (1) }\end{array}$ & $\begin{array}{l}0.27 \\
(0.4)\end{array}$ & $\begin{array}{c}-0.034 \\
(0.9)\end{array}$ & $\begin{array}{l}-0.12 \\
(0.7)\end{array}$ & $\begin{array}{l}-0.16 \\
(0.6)\end{array}$ \\
\hline MEorange & $\begin{array}{l}0.062 \\
(0.8)\end{array}$ & $\begin{array}{c}-0.025 \\
(0.9)\end{array}$ & $\begin{array}{l}0.054 \\
(0.9)\end{array}$ & $\begin{array}{c}0.54 \\
(0.07)\end{array}$ & $\begin{array}{l}-0.3 \\
(0.4)\end{array}$ & $\begin{array}{c}-0.18 \\
(0.6)\end{array}$ & $\begin{array}{l}0.32 \\
(0.3)\end{array}$ & $\begin{array}{c}-0.16 \\
(0.6)\end{array}$ & $\begin{array}{c}-0.079 \\
(0.8)\end{array}$ & $\begin{array}{l}0.0064 \\
\text { (1) }\end{array}$ & $\begin{array}{l}-0.41 \\
(0.2)\end{array}$ & $\begin{array}{c}-0.27 \\
(0.4)\end{array}$ & $\begin{array}{l}0.093 \\
(0.8)\end{array}$ & $\begin{array}{l}-0.11 \\
(0.7)\end{array}$ & $\begin{array}{l}0.23 \\
(0.5)\end{array}$ & $\begin{array}{c}0.38 \\
(0.2)\end{array}$ & $\begin{array}{c}-0.041 \\
(0.9)\end{array}$ & $\begin{array}{c}-0.31 \\
(0.3)\end{array}$ \\
\hline MEroyalblue & \begin{tabular}{|c|c|}
-0.220 \\
$(0.5)$
\end{tabular} & $\begin{array}{l}0.00074 \\
(1)\end{array}$ & $\begin{array}{l}\left.4 \begin{array}{l}0.4 \\
(0.2)\end{array}\right) \\
\end{array}$ & $\begin{array}{l}0.41 \\
(0.2)\end{array}$ & $\begin{array}{c}-0.0048 \\
(1)\end{array}$ & $\begin{array}{rl}8 & 0.28 \\
(0.4) & \end{array}$ & $\begin{array}{l}-0.14 \\
(0.7)\end{array}$ & $\begin{array}{l}0.12 \\
(0.7)\end{array}$ & $\begin{array}{l}-0.36 \\
(0.2)\end{array}$ & $\begin{array}{c}0.0092 \\
(1)\end{array}$ & $\begin{array}{l}-0.07 \\
(0.8)\end{array}$ & $\begin{array}{l}-0.39 \\
(0.2)\end{array}$ & $\begin{array}{l}-0.27 \\
(0.4)\end{array}$ & $\begin{array}{l}0.048 \\
(0.9)\end{array}$ & $\begin{array}{l}-0.035 \\
(0.9)\end{array}$ & $\begin{array}{l}0.14 \\
(0.7)\end{array}$ & $\begin{array}{l}-0.3 \\
(0.3)\end{array}$ & $\begin{array}{c}-0.33 \\
(0.3)\end{array}$ \\
\hline MEdarkturquoise & \begin{tabular}{|l|}
0.49 \\
$(0.1)$
\end{tabular} & $\begin{array}{l}0.1 \\
(0.8)\end{array}$ & $\begin{array}{l}-0.18 \\
(0.6)\end{array}$ & $\begin{array}{l}0.15 \\
(0.7)\end{array}$ & $\begin{array}{l}0.27 \\
(0.4)\end{array}$ & $\begin{array}{l}-0.56 \\
(0.06)\end{array}$ & $\begin{array}{l}0.25 \\
(0.4)\end{array}$ & $\begin{array}{l}0.17 \\
(0.6)\end{array}$ & $\begin{array}{c}0.51 \\
(0.09)\end{array}$ & $\begin{array}{c}0.1 \\
(0.8)\end{array}$ & $\begin{array}{l}-0.51 \\
(0.09)\end{array}$ & $\begin{array}{l}0.49 \\
(0.1)\end{array}$ & $\begin{array}{l}0.22 \\
(0.5)\end{array}$ & $\begin{array}{l}0.16 \\
(0.6)\end{array}$ & $\begin{array}{c}-0.002 \\
\text { (1) }\end{array}$ & $\begin{array}{l}-0.2 \\
(0.5)\end{array}$ & $\begin{array}{l}0.022 \\
(0.9)\end{array}$ & $\begin{array}{l}-0.2 \\
(0.5)\end{array}$ \\
\hline MEdarkred & $\begin{array}{c}0.58 \\
(0.05)\end{array}$ & $\begin{array}{l}-0.55 \\
(0.06)\end{array}$ & $\begin{array}{l}-0.75 \\
(0.005)\end{array}$ & $\begin{array}{c}-0.089 \\
(0.8)\end{array}$ & $\begin{array}{c}9.2 \\
(0.5)\end{array}$ & $\begin{array}{l}-0.61 \\
(0.04)\end{array}$ & $\begin{array}{c}0.62 \\
(0.03)\end{array}$ & $\begin{array}{l}0.24 \\
(0.5)\end{array}$ & $\begin{array}{l}0.25 \\
(0.4)\end{array}$ & $\begin{array}{c}0.71 \\
(0.009)\end{array}$ & $\begin{array}{l}-0.38 \\
(0.2)\end{array}$ & $\begin{array}{l}0.064 \\
(0.8)\end{array}$ & $\begin{array}{l}0.19 \\
(0.6)\end{array}$ & $\begin{array}{l}0.17 \\
(0.6)\end{array}$ & $\begin{array}{c}0.52 \\
(0.08)\end{array}$ & $\begin{array}{c}0.6 \\
(0.04)\end{array}$ & $\begin{array}{l}0.025 \\
(0.9)\end{array}$ & $\begin{array}{l}-0.38 \\
(0.2)\end{array}$ \\
\hline MEpaleturquoise & $\begin{array}{c}0.82 \\
(0.001)\end{array}$ & $\begin{array}{l}-0.06 \\
(0.4)\end{array}$ & $\begin{array}{l}-0.51 \\
(0.09)\end{array}$ & $\begin{array}{l}0.17 \\
(0.6)\end{array}$ & $\begin{array}{c}0.54 \\
(0.07)\end{array}$ & $\begin{array}{l}-0.87 \\
\left(2 e^{-044}\right.\end{array}$ & $\begin{array}{l}0.36 \\
(0.2)\end{array}$ & $\begin{array}{l}0.28 \\
(0.4)\end{array}$ & $\begin{array}{c}0.72 \\
(0.009)\end{array}$ & $\begin{array}{l}0.56 \\
(0.06)\end{array}$ & $\begin{array}{l}-0.63 \\
(0.03)\end{array}$ & $\begin{array}{c}0.62 \\
(0.03)\end{array}$ & $\begin{array}{l}0.25 \\
(0.4)\end{array}$ & $\begin{array}{l}0.16 \\
(0.6)\end{array}$ & $\begin{array}{l}0.36 \\
(0.2)\end{array}$ & $\begin{array}{l}0.056 \\
(0.9)\end{array}$ & $\begin{array}{l}0.026 \\
(0.9)\end{array}$ & $\begin{array}{l}-0.27 \\
(0.4)\end{array}$ \\
\hline MEgrey & $\begin{array}{l}-0.25 \\
0.45 \\
(0.4)\end{array}$ & $\begin{array}{l}-0.17 \\
(0.6) \\
\end{array}$ & $\begin{array}{c}-0.11 \\
(0.7) \\
\end{array}$ & $\begin{array}{r}0.2 \\
(0.5) \\
\end{array}$ & $\begin{array}{c}-0.39 \\
(0.2) \\
\end{array}$ & $\begin{array}{c}-0.026 \\
(0.9) \\
\end{array}$ & $\begin{array}{l}0.24 \\
(0.4) \\
\end{array}$ & $\begin{array}{l}0.12 \\
(0.7)\end{array}$ & $\begin{array}{l}-0.13 \\
(0.7) \\
\end{array}$ & $\begin{array}{c}-0.058 \\
(0.9) \\
\end{array}$ & $\begin{array}{c}0.0056 \\
\text { (1) }\end{array}$ & $\begin{array}{l}0.15 \\
(0.6)\end{array}$ & $\begin{array}{c}-0.093 \\
(0.8) \\
\end{array}$ & $\begin{array}{l}0.44 \\
(0.2)\end{array}$ & $\begin{array}{l}-0.11 \\
(0.7)\end{array}$ & $\begin{array}{c}-0.011 \\
(1)\end{array}$ & $\begin{array}{l}-0.2 \\
(0.5) \\
\end{array}$ & $\begin{array}{l}-0.25 \\
(0.4) \\
\end{array}$ \\
\hline
\end{tabular}




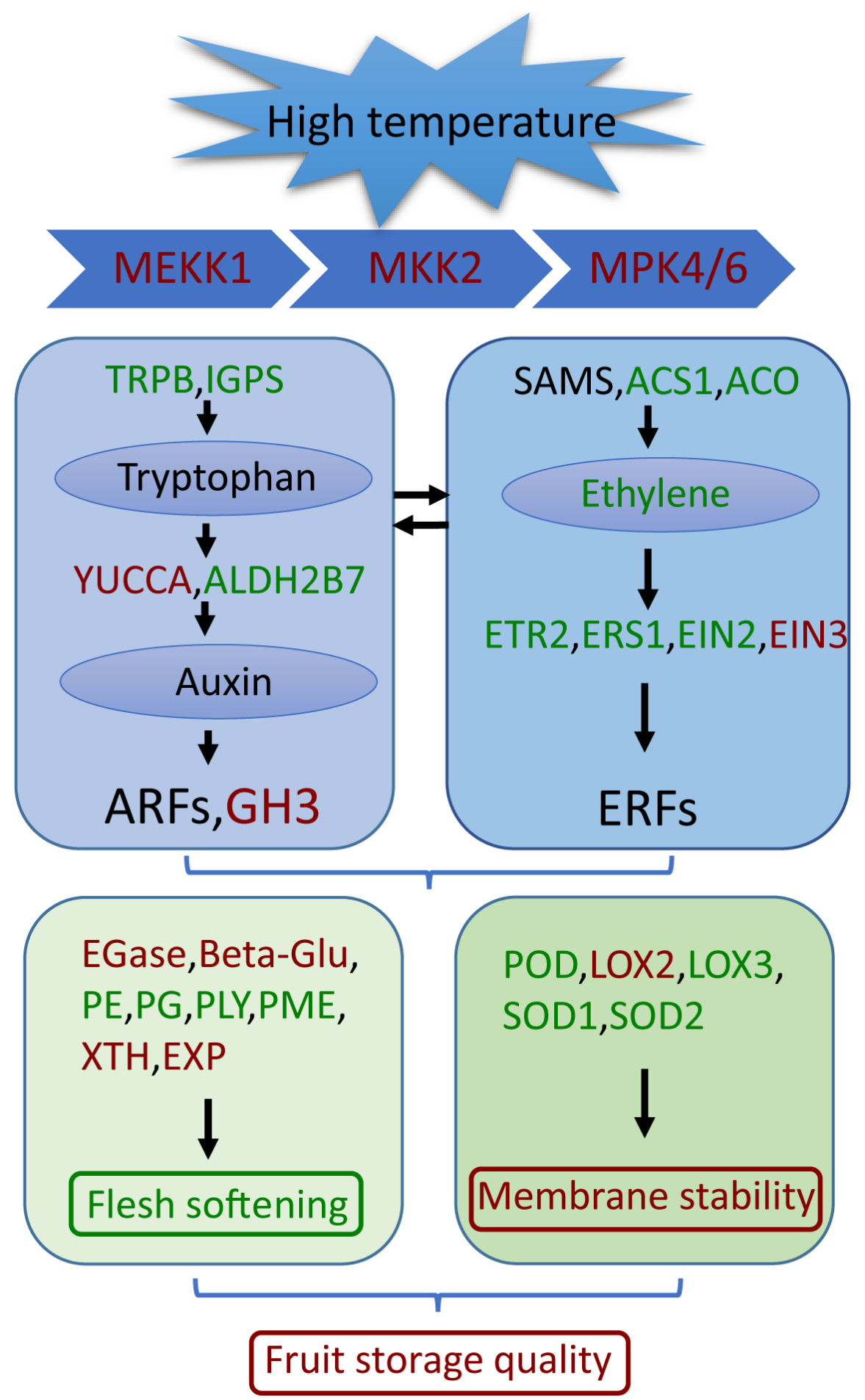

